\title{
Towards a Revision of Candoninae (Crustacea: Ostracoda): Description of Two New Genera from Australian Groundwaters
}

\author{
Ivana Karanovic \\ Western Australian Museum, Francis Street, Perth, W.A. 6000, Australia \\ E-mail: karanovic@museum.wa.gov.au
}

(Received 23 November 2002; Accepted 25 July 2003)

\begin{abstract}
The present paper contains descriptions of the following ostracod taxa from subterranean waters of Western Australia: Meridiescandona lucerna $\mathrm{n}$. gen., n. sp; M. facies n. gen., n. sp., and Deminutiocandona mica n. gen., n. sp. They all belong to the subfamily Candoninae, and these findings bring the number of genera of Candoninae to 24. Meridiescandona is characterized by decorated valves, a 6-segmented antennula, and full development of furcal elements. Deminutiocandona stands apart from other candonine genera by having a 5-segmented antennula, a reduced anterior furcal claw, and $4+2$ rows of spines on the Zenker's organ. The morphologies of the new genera are discussed and compared with those of the other known genera of this subfamily.
\end{abstract}

Key Words: ostracods, candonids, Meridiescandona n. gen., Deminutiocandona n. gen., taxonomy, systematics, groundwater.

\section{Introduction}

Candona candida (Müller, 1776) is the first described species belonging to the subfamily Candoninae Kaufmann, 1900. It was originally placed in the genus Cypris Müller, 1776, but later on Baird (1845) described the genus Candona and transferred Cypris candida Müller, 1776 into it. This species became the type species of the genus Candona Baird, 1845, which is the oldest candonine genus. Today, this subfamily comprises about 300 living representatives and many other fossil ones. The generic diagnosis given by Baird (1845: 152-153) is sparse: "Two pairs of feet, one pair contained within the shell. Abdomen terminated by long slender bifid tale. Pediform antennae not furnished with a pencil of long hairs or filaments. Animal creeps at the bottom, or upon aquatic plants." This diagnosis was so broad that Baird (1845) included in the same genus some species belonging to other, not even closely related, families of Cypridoidea. Candona is certainly the candonine genus to which the greatest number of species has been assigned (see Kempf 1980, 1997). The subfamily currently includes an additional 21 recent genera (see Karanovic 2003; Karanovic and Marmonier 2003). Although the number of morphological characters used in the taxonomy of the subfamily Candoninae has increased significantly since Baird (1845), it has been insufficient to prevent numerous wrong generic designations as well as synonyms.

The subfamily Candoninae, belonging to the superfamily Cypridoidea of the 
order Podocopida, was divided into two tribes when Martens (1992) created the tribe Namibcypridini for the genus Namibcypris Martens, 1992 which he described from Africa, and the genus Danielocandona Broodbakker, 1983 described from Central America by Broodbakker (1983). All the other genera (16 at that time) remained together in the tribe Candonini. Martens (1992) included only recent genera in this systematic arrangement. Krstic and Guan (2000) gave a much broader systematic division, creating 20 tribes that included: "all Neogene-Recent, a majority of Early Tertiary and some of Mesozoic genera". This systematic account has many confusing elements for those who work on recent Candoninae, because some closely related genera are classified in different tribes based only on carapace shape. A detailed revision of the subfamily, which should have a proper balance between recent and fossil representatives, is certainly needed; however, this can be done only after revision of some of the very diverse candonine genera, such as Eucandona Daday, 1900 sensu Petkovski and Karanovic (2000) [=Fabaeformiscandona Krstic, 1972 sensu Meisch (2000)], Candona s. str. Baird, 1845, and Pseudocandona Kaufmann, 1900, which unite species with highly diverse morphological characters.

Unfortunately, ostracods, like many other invertebrate groups, are not equally investigated in all parts of the world. Those of Western and Central Europe are well known (see Meisch 2000) and the extinction of some taxa, caused by human activities, would be less surprising than finding of new ones. The situation in the rest of Europe is different; for example, ostracods are much more poorly known in the Balkan Peninsula. Owing to its geomorphology, this region was an important refuge for many species during the Pleistocene Ice Ages, and some endemic ostracod taxa have been described even recently (Karanovic 1999a-c, 2000; Karanovic and Petkovski 1999a, b). In all other parts of the world the freshwater ostracod fauna is even less well known, with the Australian continent amongst the most poorly known. Research on the Australian freshwater ostracod fauna dates back to the middle of the 19th century (King 1855), but only about 130 recent species have been described so far, all being surface water inhabitants, mostly $(81 \%, 105$ species) belonging to the family Cyprididae. Among those 130 species, only Candonopsis tenuis (Brady, 1886) unequivocally belongs to the family Candonidae and subfamily Candoninae. Recently the investigation of the subterranean biota of Australia has increased markedly, and as a result many new endemic taxa have been discovered (Poore and Humphreys 1992, 1998; Wilson and Ponder 1992; Humphreys 1993a-c, 2001; Bruce and Humphreys 1993; Harvey et al. 1993; Pesce et al. 1996a, b; Pesce and De Laurentis 1996; Yager and Humphreys 1996; Bradbury and Williams 1996a, b, 1997a, b; Harvey 1998; De Laurentis et al. 1999, 2001; Watts and Humphreys 1999; Danielopol et al. 2000; Jaume and Humphreys 2001; Jaume et al. 2001; Karanovic et al. 2001; Karanovic and Pesce 2002; Lee and Huys 2002). These investigations, led by the Western Australian Museum, did not overlook the ostracod fauna which, in those subterranean ecosystems, mainly comprises representatives of Candoninae. This has resulted, so far, in the description of four genera and 16 species, all belonging to this subfamily (Karanovic 2003; Karanovic and Marmonier 2003).

Each Australian genus combines several diagnostic features of other known genera, as well as having its own unique characteristics. As a consequence, in light of the great number of species described worldwide and the dubious system- 
atic position of the Australian forms within the Candoninae, there is a need to revise the subfamily and to establish more rigorous phylogenetic hypotheses. This paper is a further contribution to the knowledge of the Australian ostracod fauna. It contains the descriptions of two new genera and three new species belonging to the subfamily Candoninae, which were collected during an intensive investigation of the subterranean ecosystems of Western Australia. It is also a contribution to the revision of the subfamily Candoninae, introducing new morphological features and discussing their importance throughout the subfamily.

\section{Methods}

Samples were collected with haul-nets (mesh size 250 or $350 \mu \mathrm{m}$ ) from bores and wells, and with the Bou-Rouch phreatic pump from a spring's interstitial. Bores are holes in the calcrete systems mainly made by mining companies for the purposes of water monitoring and usage or mineral exploration. They are usually 10 to $20 \mathrm{~cm}$ in diameter and may be lined entirely, or in part, by PVC tubing (the casing). This tubing may be open only at the bottom or it may be pierced at one or more levels by holes of various sizes, referred to as "slots". The top may be securely capped or entirely open to the elements. Some bores record the water pressure at a given level in the aquifer (piezometers), while others, together with handdug wells (ca. $1 \times 1.5 \mathrm{~m}$ ) equipped with windmills, provide water for pastoral use. Many of these features are derelict. Many bores put in for hydrogeological work, mineral exploration, and water monitoring have prefixes or suffixes of relevance only to that drilling program. These codes are cited just to aid specification of the location.

Haul-nets are simple plankton nets of different sizes suitable for the respective bores, which can range from 30 to $180 \mathrm{~mm}$ in diameter. To take a sample a weighed net is lowered into a bore with a bottle screwed onto its distal part, then hauled up through the water column, usually a number of times. All samples were sorted while alive under a dissecting microscope and the ostracods were then fixed in $75 \%$ ethanol.

Ostracods were dissected in a mixture of distilled water and glycerol $(1: 1)$ with fine entomological needles (mark 000). Dissected appendages and valves of some specimens were mounted in Faure's medium. All non-dissected material is preserved in $75 \%$ ethyl-alcohol in glass test-tubes. Drawings have been prepared using a drawing tube attachment on Leica-DMLS microscope, with C-PLAN achromatic objectives. All the material is deposited in the Western Australian Museum (numbers WAM C28412 to WAM C28423).

In the systematic part of this paper the reported length of all segments is from measurements in the middle of the segments, and length ratios are presented beginning with the proximal end. The names of all appendages follow Martens (1998). The chaetotaxy of all limbs follows the model proposed by Broodbakker and Danielopol (1982), revised for the antenna by Martens (1987), and for the third thoracopod by Meisch (1996). Lobes on the hemipenis are marked according to Danielopol (1969). In front of the abbreviations for the setae on the endopodal segments of the first and third thoracopods the letter "T" is added, so not to be confused with the abbreviations for the hemipenis. 
Abbreviations used in text and figure legends: a, lateral (or outer) lobe on hemipenis; A1, antennula; A2, antenna; b, medial lobe on hemipenis; BES, prefix for field number; e, bursa copulatrix; d1, d2, and dp, setae on basal segment of T3; $\mathrm{Fu}$, furca; g, "M" process (middle chitinous part) of hemipenis; G1, G2, G3, GM, and $\mathrm{Gm}$, antennal claws; $\mathrm{H}$, height; $\mathrm{h}$, inner lobe on hemipenis; $\mathrm{L}$, length; LV, left valve; Md, mandible; Mxl, maxillula; RV, right valve; S1 and S2, setae on first segment of mandibular palp; Ta, Tb, and Td, setae on T1; Te, Tf, Tg, Th1, Th2, and Th3, setae on endopodal segments of T3; T1, T2, and T3, first, second, and third thoracopods, respectively; $\mathrm{t} 1, \mathrm{t} 2, \mathrm{t} 3$, and $\mathrm{t} 4$, setae on second endopodal segment of $\mathrm{A} 2 ; \mathrm{W}$, width; WAM, Western Australian Museum; Y, ya, y1, y2, and y3, aesthetascs; z1, z2, and $\mathrm{z} 3$, apical setae on second endopodal segment of A2.

\section{Results \\ Family Candonidae Kaufmann, 1900 \\ Subfamily Candoninae Kaufmann, 1900 \\ Genus Meridiescandona n. gen.}

Type species: Meridiescandona lucerna $\mathrm{n}$. sp.

Other species: Meridiescandona facies n. sp.

Diagnosis. Carapace sub-rectangular and ornamented. LV overlapping RV on all free margins. Antennula six-segmented; third and fourth segments fused. Second antenna with only one "t" seta and one " $z$ " claw in both sexes. Mandibular palp four-segmented. Second segment with two setae on outer edge, and with bunch of $3+2$ setae on inner edge. Penultimate segment with two setae externomedially, one externo-distally, and three interno-medially to interno-distally. Terminal segment with fused claw. $\mathrm{L}: \mathrm{W}$ ratio of terminal segment less than $2: 1$. Terminal segment of maxillular palp square to trapezoidal. Claws on third endite plumose. $\mathrm{T} 1$ with one Ta seta. Both $\mathrm{Tb}$ and $\mathrm{Td}$ setae present. Exopodite of same appendage with three rays. Prehensile palps almost symmetrical with elongated fingers and long subterminal sclerotized structures. T2 five-segmented and lacking seta on basal segment. Setae on penultimate segment short. T3 five-segmented. Basal segment with dp, d1, and d2 setae. Also, all other endopodal setae (Te, Tf, Tg, Th1, Th2, and Th3) developed. Terminal segment with two short (Th1, Th2) and one long (Th3) setae, and with subterminal spines. Furca with all claws and setae. Genital lobe rounded and without appendages. Hemipenis with stocky appearance. Lobe "a" not extended dorsally and with obtuse posterior margin. Lobe " $b$ " with one well-chitinized structure passing into oblong margin towards dorsal side and inclined margin towards ventral side. Lobe " $h$ " double-folded and rounded. Central chitinized part (g) well sclerotized in its proximal part, while distally so only on its outer margins; also, this part protrusible between lobes. Zenker's organ with $5+2$ rows of spines.

Etymology. The genus name is composed of two words: meridies, a Latin noun (gender feminine) meaning south, and the genus name Candona (gender feminine). 


\section{Meridiescandona lucerna $\mathrm{n} . \mathrm{sp}$.}

(Figs 1-25)

Material. Holotype (male on slide, WAM C28412), allotype (female on slide, WAM C28413), and eight paratypes (one male on slide, WAM C28414; one male and six juveniles in alcohol, WAM C 28415) from the Battle Hill Well, Roy Hill Station, Fortescue River Valley, Pilbara Region, Western Australia, $22^{\circ} 44^{\prime} \mathrm{S}, 120^{\circ} 08^{\prime} \mathrm{E}, 08$ September 2000, collectors W. F. Humphreys and J. M. Waldock (BES: 8507). Three males, four females, and one juvenile (all in alcohol, WAM C28416) from the Aerodrome Bore, Roy Hill Station, Fortescue River Valley, Pilbara Region, Western Australia, $22^{\circ} 43^{\prime}$ S, $120^{\circ} 55^{\prime}$ E, 08 September 2000, collectors W. F. Humphreys and J. M. Waldock (BES: 8500).

Description. Holotype (male, $\mathrm{L}=0.596 \mathrm{~mm}$ ). Carapace sub-rectangular in lateral view. $\mathrm{L}$ of $\mathrm{LV}=0.596 \mathrm{~mm}$ (Fig. 4); $\mathrm{L}$ of $\mathrm{RV}=0.581 \mathrm{~mm}$ (Fig. 2). Greatest $\mathrm{H}$ on both valves lying at last third of $\mathrm{L}$, equal to $54 \%$ of $\mathrm{L}$. Dorsal margin straight in middle but sloping gradually towards anterior end, and slightly sinusoid antero-dorsally while widely rounded postero-dorsally. Both anterior and posterior margins widely rounded, posterior one being slightly narrower. Outer margin on anterior end also notched. Ventral margin slightly concave in mouth region. Valve surface covered with long hairs, especially on posterior end. Surface with reticular patterns covering all except anterior part; there, flower-like patterns of warts surrounded by small circle patterns, present. Warts also visible in dorsal view. Anterior marginal zone $16.5 \%$, while posterior one $8.0 \%$ of total L. Fused zone narrow with short, dense pore canals. Selvage visible, peripheral. Flange developed on LV postero-dorsally, antero-dorsally, and ventrally (Fig. 4). In dorsal view anterior and posterior ends equally rounded, not pointed. LV overlapping RV very slightly at both ends. Greatest $\mathrm{W}$ at around middle, equal to $33 \%$ of $\mathrm{L}$.

A1 (Fig. 8) six-segmented. Third and fourth segments fused. First segment with one seta antero-proximally (not shown in Fig. 8), one antero-distally, and two long setae posteriorly; second segment with one seta anteriorly (reaching almost middle of following segment); third segment with two setae distally (both short and reaching slightly beyond middle of following segment); fourth segment with one seta antero-distally (almost reaching distal end of penultimate segment); penultimate segment with three long setae distally; terminal segment with two long and one short setae (shorter one about 2.5 times as long as terminal segment) and aesthetasc (ya), latter about 4.3 times as long as terminal segment (Fig. 9). L ratio of four distal segments $1.5: 1: 1.7: 1.27$.

A2 (Fig. 7) with three-segmented endopodite, and without male bristles. Exopodite plate with two short and one longer setae (about 2.6 times longer than the shortest one). Aesthetasc Y 0.74 times as long as first endopodal segment; aesthetasc y1 not reaching distal margin of penultimate segment; y2 slightly exceeding distal margin of terminal segment; y3 0.6 times as long as first endopodal segment. Penultimate segment with one medial seta on each side of appendage; posterior one (t1) long, well exceeding distal end of terminal segment; anterior one short, not reaching distal end of penultimate segment. Penultimate segment also with three distal claws (G1, G2, and $\mathrm{z} 1$ ), as well as one more seta representing transformed G3 claw. Claws G2 and z1 subequally long, about 1.13 times longer than first endopodal segment. Claw G1 short and 3.4 times longer than terminal 

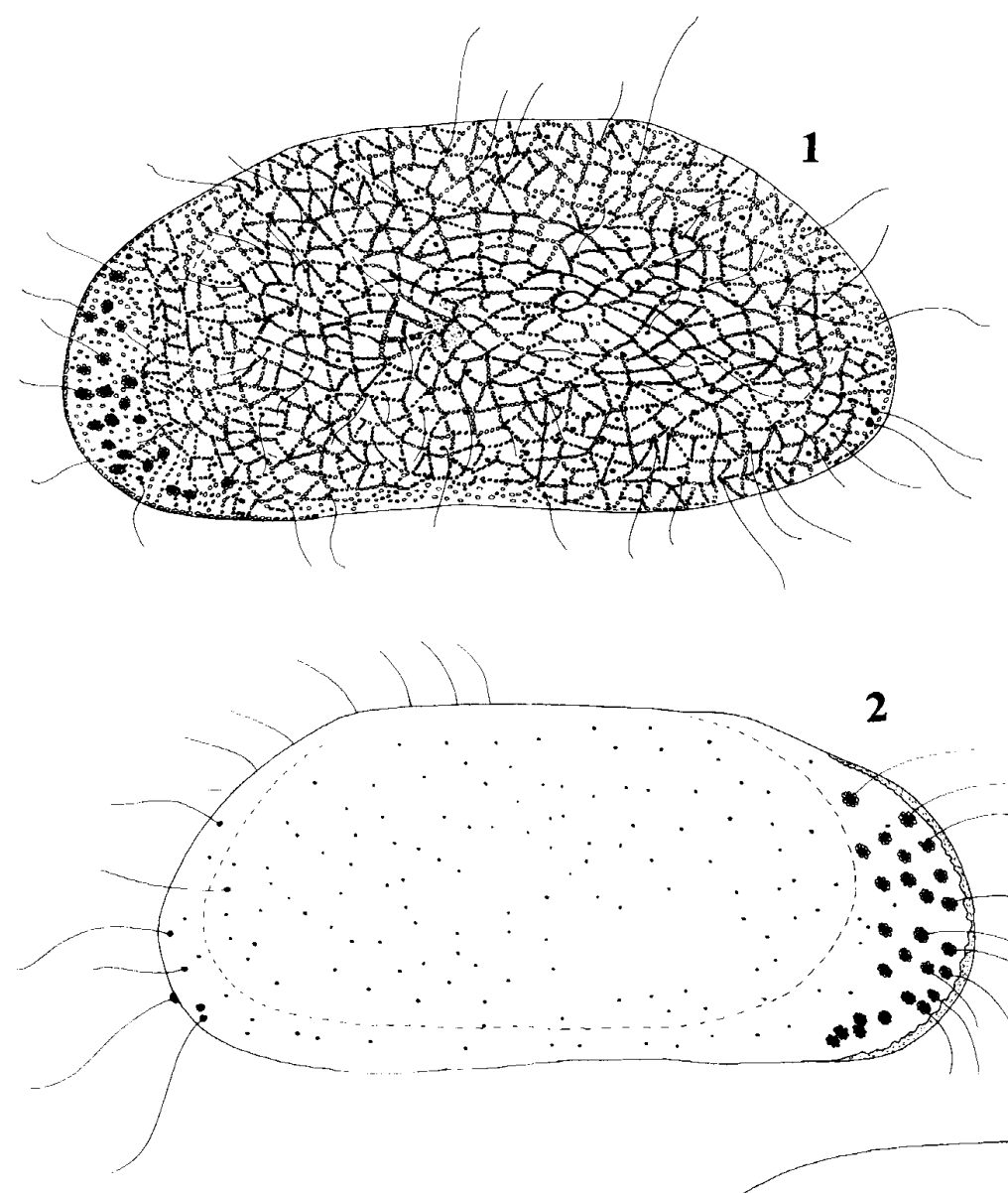

\section{2}
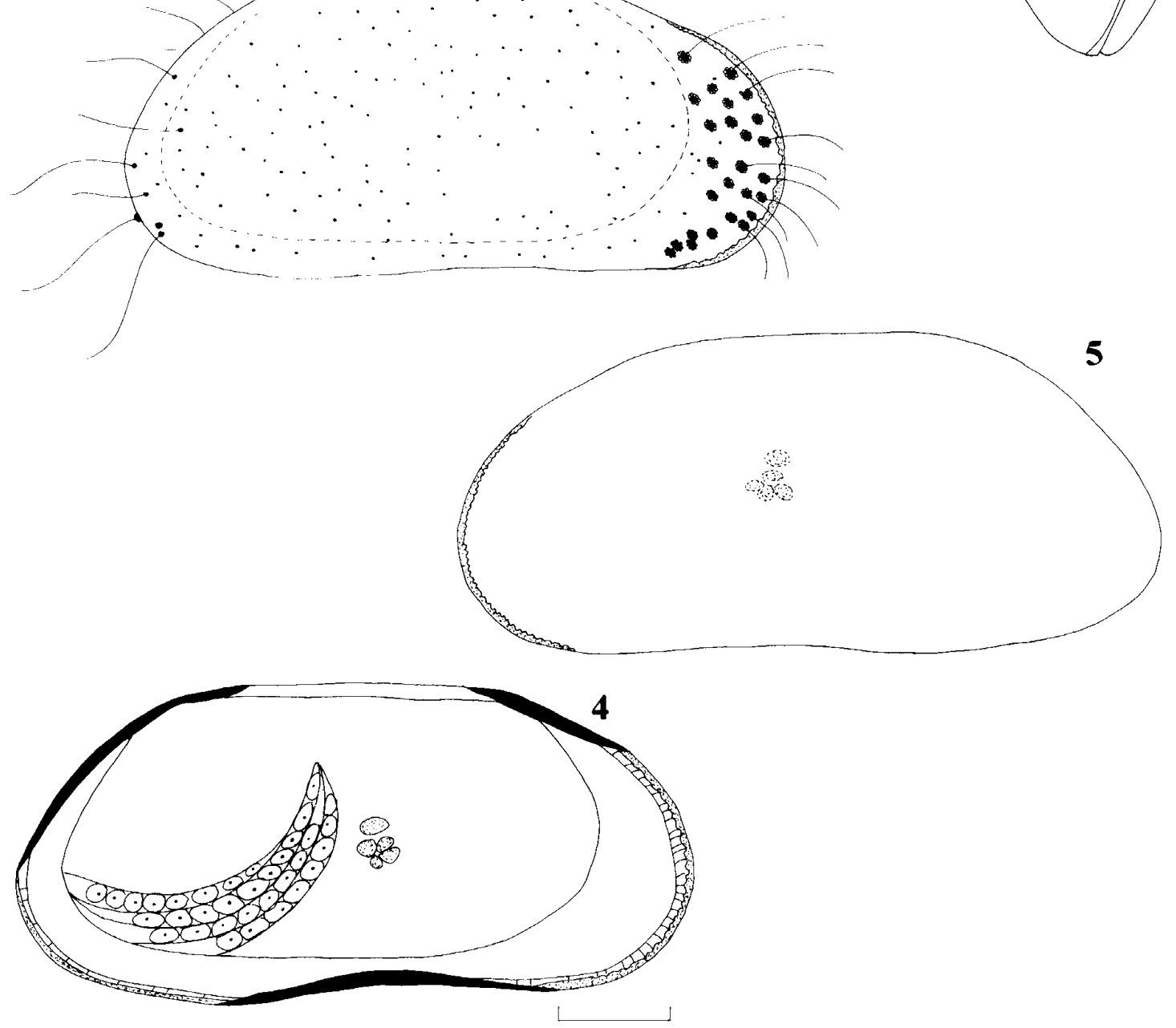

Figs 1-5. Meridiescandona lucerna $\mathrm{n}$. gen., n. sp. 1, 3, paratype male ( $\mathrm{L}=0.606 \mathrm{~mm}) ; 2,4$, holotype male $(\mathrm{L}=0.596 \mathrm{~mm}) ; 5$, allotype female $(\mathrm{L}=619 \mathrm{~mm}) .1$, $\mathrm{LV}$, external view; $2, \mathrm{RV}$, external view, ornamentation only partly presented; 3 , carapace, dorsal view; 4 , $L V$, internal view; 5 , LV, external view. Scale $=0.1 \mathrm{~mm}$. 


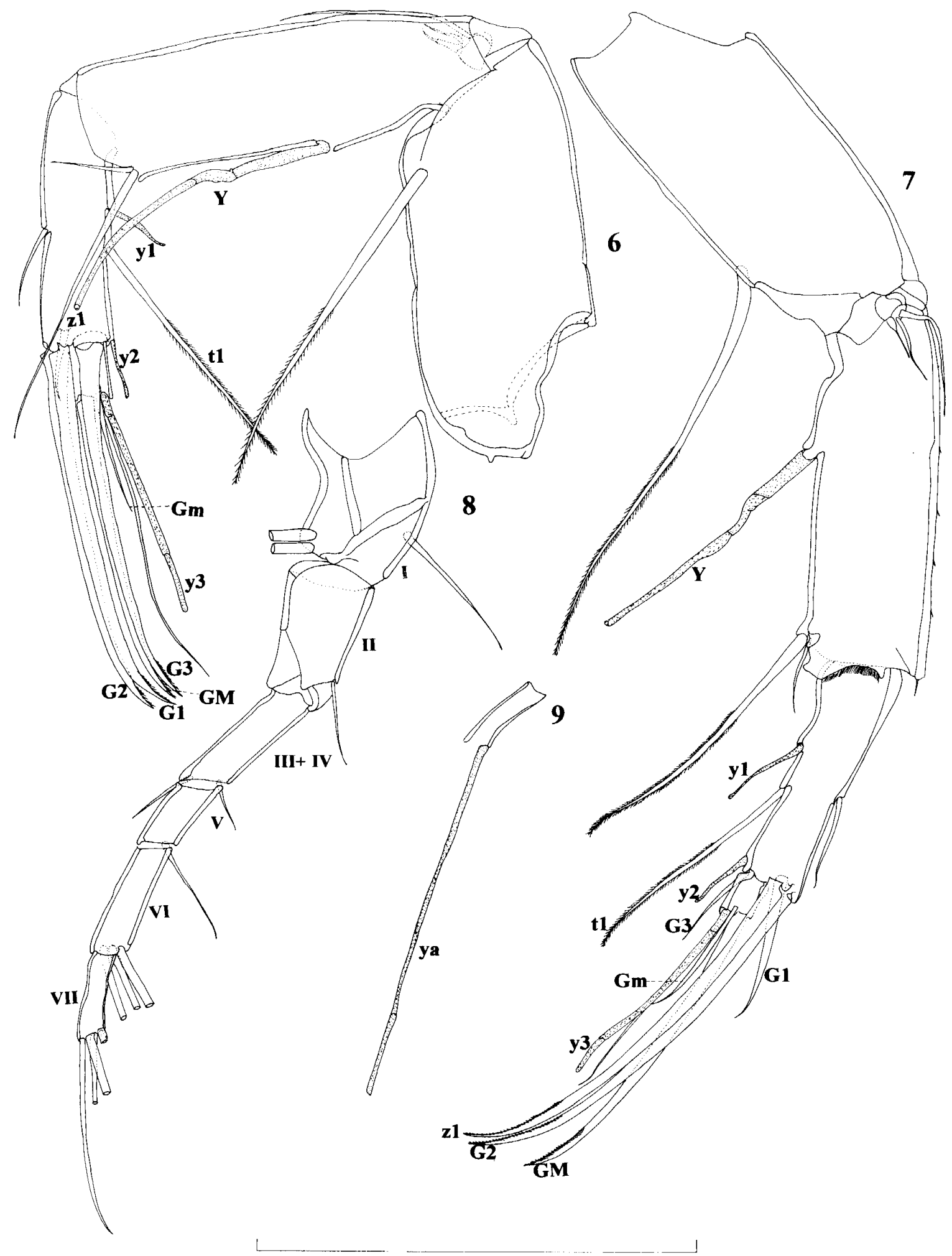

Figs 6-9. Meridiescandona lucerna n. gen., n. sp. 6, allotype female $(\mathrm{L}=619 \mathrm{~mm}) ; 7,8$, holotype male $(\mathrm{L}=0.596 \mathrm{~mm}) .6,7, \mathrm{~A} 2 ; 8, \mathrm{~A} 1 ; 9$, terminal segment of $\mathrm{A} 1$ with aesthetasc. Setae labelled in 6 and 7 ; segments numbered in 8 . Scale $=0.1 \mathrm{~mm}$. 
segment. Claw G3 also short and about 2 times longer than terminal segment. Setae z2 and z3 missing. Terminal segment with long GM claw (0.92 times as long as first endopodal segment) and short Gm claw (2.8 times as long as terminal segment). $\mathrm{L}$ ratio of three endopodal segments $8: 5.3: 1$.

Md (Fig. 10) with well developed coxa; palp four-segmented. First segment with two plumose setae (short S2 and long S1) and two smooth setae (short alpha seta, and one long seta) on inner edge. Second segment with two short setae on outer edge and $3+2$ setae in bunch on inner edge. Following segment with two setae externo-medially (one almost reaching distal end of terminal claw, other just reaching distal end of same segment); gamma seta externo-distally (slightly exceeding distal end of terminal segment); and three setae interno-medially to interno-distally. Terminal segment with fused and distally plumose claw, one strong plumose seta externally, and two weaker smooth setae internally. L ratio of three distal segments $1: 3.7: 1.2$.

Mxl palp (Fig. 11) with square to trapezoidal terminal segment bearing two claw-like and three thin setae. Penultimate segment of same appendage with four pappose setae. Claws on third endite plumose (Fig. 12).

Rake-like organ (Fig. 13) with about 19 teeth.

Prehensile palps (Figs 14, 15) symmetrical with elongated fingers and long, thin subapical structures. Exopodite with three rays. One each of $\mathrm{Ta}, \mathrm{Tb}$, and $\mathrm{Td}$ setae present.

T2 five-segmented (Fig. 17). Basal segment without seta, first endopodal segment with one seta (almost reaching middle of following segment). Second endopodal segment with one seta, penultimate segment with two setae. Terminal segment with two distal setae and claw. Claw distally serrated and as long as three distalmost segments combined.

T3 five-segmented (Fig. 18). Basal segment with $d 1$, d2, and dp setae. Also, all other endopodal setae present. $\mathrm{L}$ ratio of three distal setae $1: 2: 7.4$. Seta Th3 with two lateral spines.

Furca (Fig. 23) with both anterior and posterior setae developed, posterior one just reaching distal end of posterior margin. Also, both claws well developed and anterior one with well-defined spine. $\mathrm{L}$ ratio of anterior margin and anterior and posterior claws 2.55:1.33:1. Furcal attachment shown in Fig. 22.

Hemipenis (Fig. 19) with triangular "a" lobe (rounded distal margin). Lobe "b" with acute, well-sclerotized, more medially positioned part, as well as rounded, more dorsally positioned part. Lobe " $h$ " double-folded and with widely rounded distal margin. M process (g) rounded, well sclerotized in its proximal part, while distally so only on outer margins, not protruding between lobes. Zenker's organ with $5+2$ rows of spines.

Allotype (female, $\mathrm{L}=0.619 \mathrm{~mm}$ ). Carapace (Fig. 5) same as in male. Greatest $\mathrm{H}$ on both valves equal to $54.5 \%$ of $\mathrm{L}$, greatest $\mathrm{W}$ same as in male.

A2 (Fig. 6) with three long claws (G1, G2, and G3) and only z1 seta on penultimate segment. Long claws subequally long, about 0.98 times as long as first endopodal segment, while $\mathrm{z} 1$ as long as terminal segment. As in male, only one t-seta present. Terminal segment with one long GM claw (0.87 times as long as first endopodal segment) and short Gm (1.8 times as long as terminal segment). Length ratio of endopodal segments $5.5: 3.7: 1$. Longest seta on exopodite longer than in male, 4.4 times longer than shortest one. 


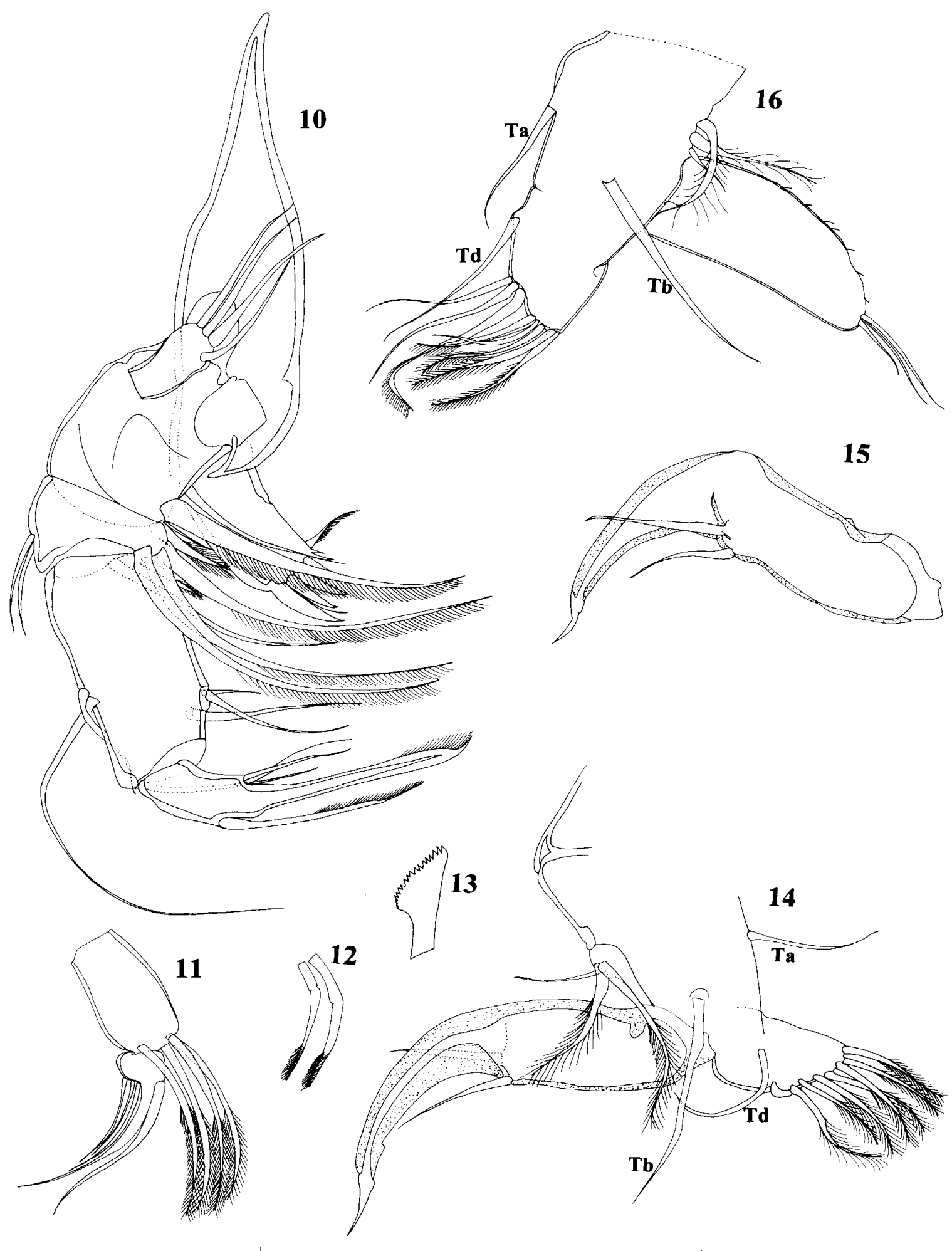

Figs 10-16. Meridiescandona lucerna n. gen., n. sp. 10-15, holotype male ( $\mathrm{L}=0.596 \mathrm{~mm}) ; 16$, allotype female $(\mathrm{L}=619 \mathrm{~mm}$ ). 10, Md; 11 , Mxl palp; 12, claws on third endite of $\mathrm{Mxl} ; 13$, Rake-like organ; 14 , left prehensile palp; 15 , right prehensile palp; 16 , T1. Some setae labelled in 14 and 16. Scale $=0.1 \mathrm{~mm}$. 


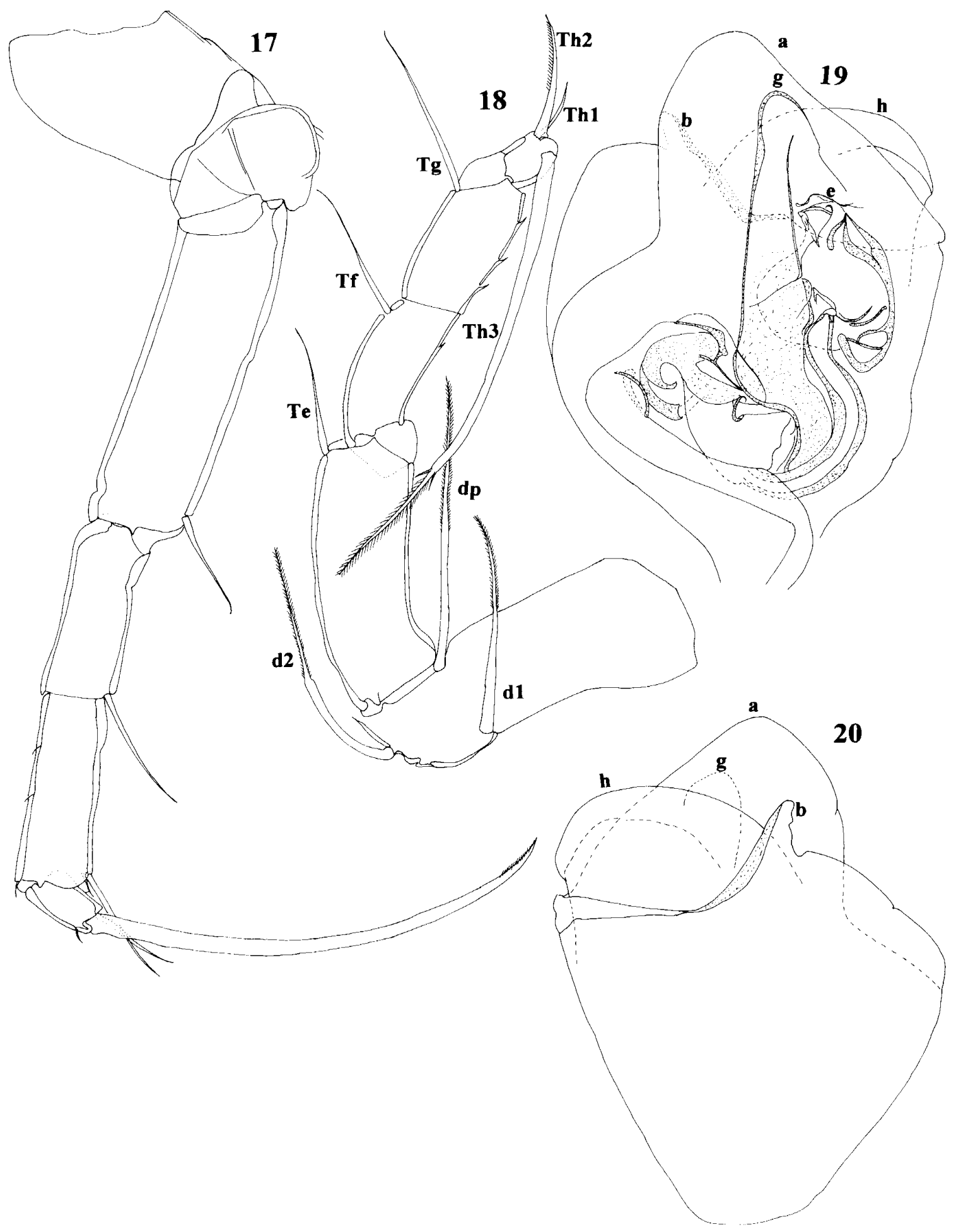

Figs 17-20. Meridiescandona lucerna $\mathrm{n}$. gen., n. sp. 17-19, holotype male ( $\mathrm{L}=0.596 \mathrm{~mm}) ; 20$, paratype male $(\mathrm{L}=0.606 \mathrm{~mm}) .17, \mathrm{~T} 2 ; 18, \mathrm{~T} 3 ; 19$, hemipenis, lateral view; 20 , hemipenis, medial view. Setae labelled in 18, lobes labelled in 19 and 20 . Scale $=0.1 \mathrm{~mm}$. 


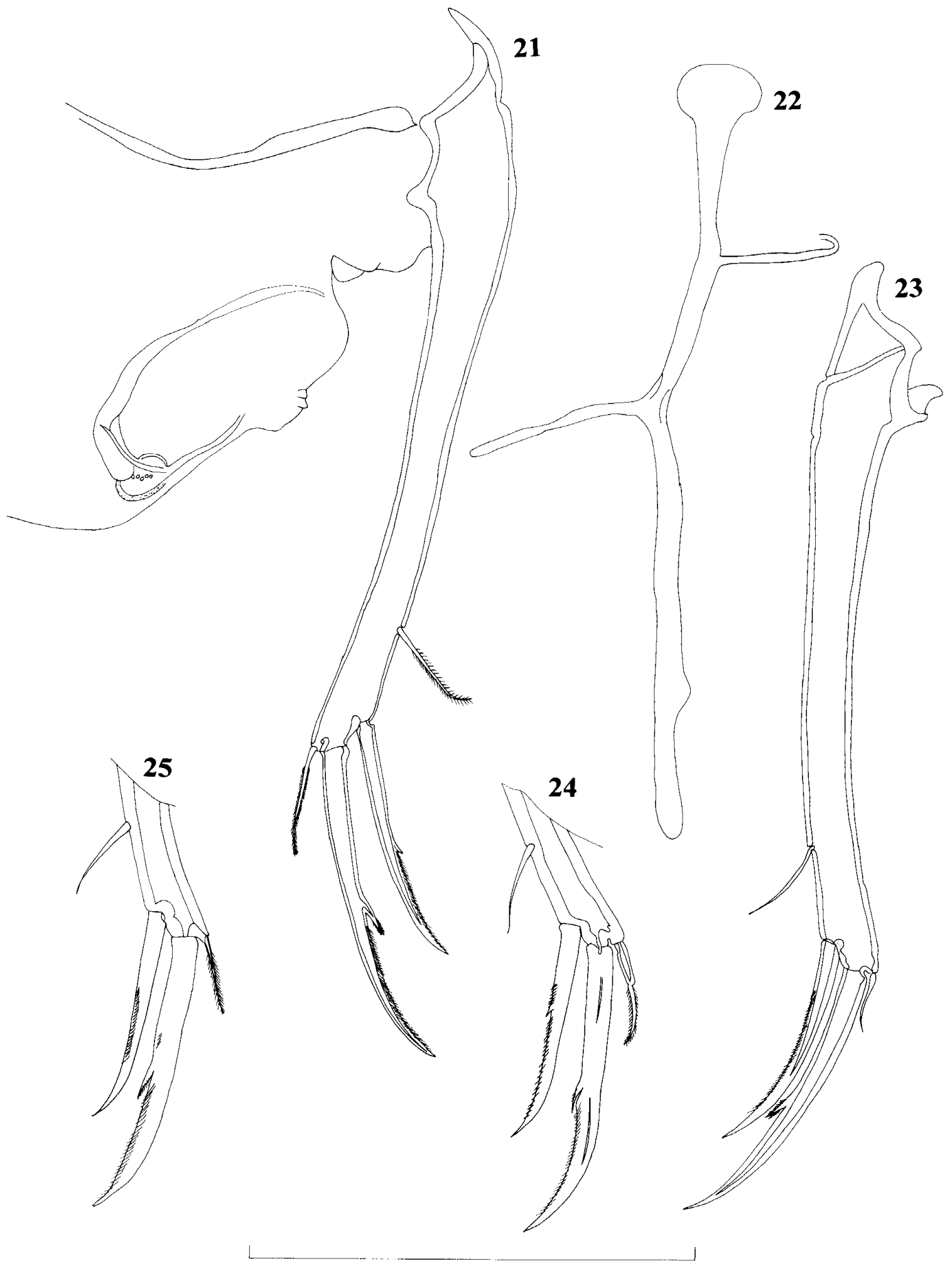

Figs 21-25. Meridiescandona lucerna $\mathrm{n}$. gen., n. sp. 21, allotype female $(\mathrm{L}=619 \mathrm{~mm})$; 22, 23, holotype male $(\mathrm{L}=0.596 \mathrm{~mm}) ; 24,25$, paratype male $(\mathrm{L}=0.606 \mathrm{~mm})$. 21, Fu with genital lobe; 22, furcal attachment; 23, Fu; 24, 25, distal parts of Fu. Scale $=0.1 \mathrm{~mm}$. 
Length ratio of three apical setae on endopodite T1 (Fig. 16) $1: 1.6: 1.87$. T1 also with one Ta seta, three setae on exopodite, and $\mathrm{Tb}$ and Td setae.

Genital lobe (Fig. 21) rounded, just with several folds. Both claws of furca with well developed spines. $\mathrm{L}$ ratio of anterior margin and anterior and posterior claws $2.25: 1.31: 1$.

All other appendages $\mathrm{A} 1, \mathrm{Md}, \mathrm{Mxl}, \mathrm{T} 2$, and T3 similar to those of male.

Variability. Only in the paratype male (Figs $1,20,24,25)$ is variability in the appearance of the furca noticed. On one furcal ramus both claws carry a prominent spine (Fig. 24), while on the other furcal ramus only the anterior claw has this spine (Fig. 25). There is also variability in the appearance of the anterior seta, which is well-sclerotized on one ramus (Fig. 24), but not on the other (Fig. 25).

Etymology. The specific name is a Latin noun lucerna (gender feminine) meaning lamp.

\section{Meridiescandona facies $\mathrm{n}$. sp.}

(Figs 26-47)

Material. Holotype (male on slide, WAM C28417), allotype (female on slide, WAM C28418), and four paratypes (two males, one female, and one juvenile: one male on slide, WAM C28417, all the rest in alcohol, WAM C28418) from a bore at Yandicoogina Mine (along Marillana Creek), $80 \mathrm{~km}$ north of Newman, Pilbara Region, Western Australia, $22^{\circ} 49^{\prime} \mathrm{S}, 119^{\circ} 16^{\prime} \mathrm{E}$, 04 August 1999, collector S. Anstee (HI019 YJDD319). Two males and two females (all in alcohol, WAM C28419), from Yandicoogina Mine, $80 \mathrm{~km}$ north of Newman, Pilbara Region, Western Australia, $22^{\circ} 50^{\prime} \mathrm{S}, 119^{\circ} 15^{\prime} \mathrm{E}, 03$ August 1999, collector S. Anstee (HI036 99YNB02).

Description. Holotype (male, $\mathrm{L}=0.546 \mathrm{~mm}$ ). Carapace sub-rectangular in lateral view (Fig. 26). $\mathrm{L}$ of $\mathrm{LV}=0.546 \mathrm{~mm}$ (Fig. 27); $\mathrm{L}$ of $\mathrm{RV}=0.538 \mathrm{~mm}$. Greatest $\mathrm{H}$ on both valves around middle of L, equal to $48.5 \%$ of L. Dorsal margin straight in middle, slightly sinusoidal antero-dorsally, widely rounded postero-dorsally. Both anterior and posterior margins widely rounded, posterior one slightly narrower. Ventral margin concave in middle. Valve surface covered with long hairs, especially on posterior end. Surface with linearly distributed, dot-like patterns. Anterior marginal zone $19.6 \%$ of total L, while posterior margin $18.4 \%$ of total L. Fused zone narrow with short, dense pore canals. Selvage visible, peripheral. Flange developed on LV postero- and antero-dorsally. In dorsal view (Fig. 28) anterior end slightly cuneiform, posterior end rounded. LV overlapping RV clearly on all free margins. Greatest W around middle, equal to $29.9 \%$ of $\mathrm{L}$.

A1 (Fig. 31) six-segmented. Third and fourth segments fused. First segment with one seta antero-proximally (not shown on Fig. 31), without any seta anterodistally, and with two long setae posteriorly; second segment with one seta anteriorly (reaching almost middle of following segment); third segment with two setae distally (both exceeding distal margin of following segment); fourth segment with one seta antero-distally (almost reaching distal end of penultimate segment); penultimate segment with three long and one short setae distally; terminal segment with two long and one short setae (shorter one about 2.3 times as long as terminal segment) and aesthetasc (ya) about 5.5 times as long as terminal segment (Fig. 33). L ratio of four distal segments $2.3: 1: 1.9: 1.3$. 

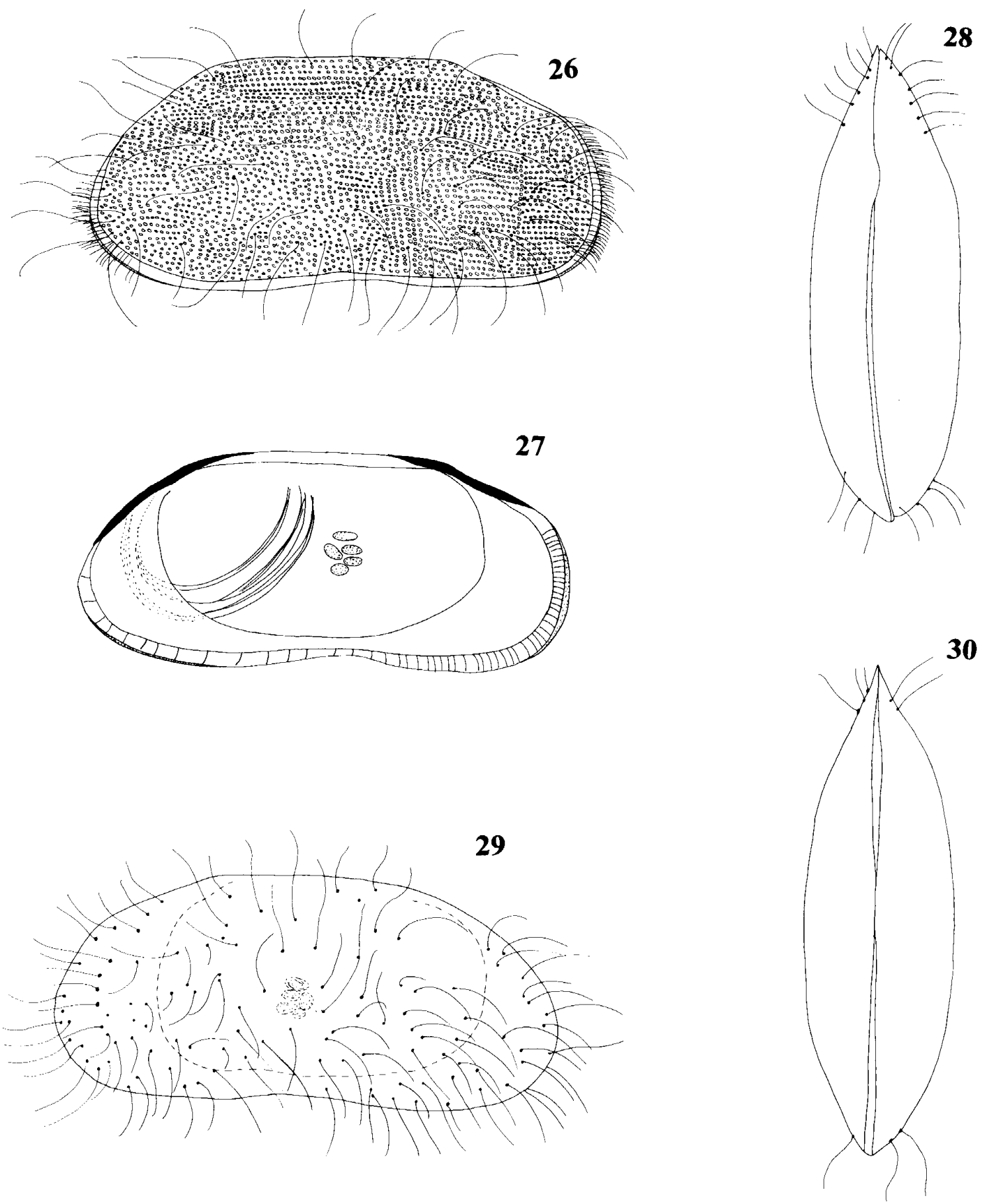

Figs 26-30. Meridiescandona facies n. gen., n. sp. 26-28, holotype male (L=0.546 mm); 29, 30, allotype female $(\mathrm{L}=0.558 \mathrm{~mm})$. 26, carapace, lateral view; $27, \mathrm{LV}$, internal view; 28 , carapace, dorsal view; $29, \mathrm{LV}$, external view, ornamentation not shown; 30, carapace, dorsal view. Scale $=0.1 \mathrm{~mm}$. 
A2 (Fig. 34) with three-segmented endopodite, and without male bristles. Exopodite plate with two short and one longer setae (about five times longer than shortest one). Aesthetasc Y 0.76 times as long as first endopodal segment; aesthetasc y1 reaching distal margin of penultimate segment; y2 slightly exceeding distal margin of terminal segment; y3 0.7 times as long as first endopodal segment. Penultimate segment with one medial setae on each side of appendage, posterior of which identified as seta $\mathrm{t} 1$. Both these setae long: $\mathrm{t} 1$ reaching middle of terminal claws, anterior one exceeding distal end of terminal segment. Penultimate segment also with three distal claws (G1, G2, and z1), as well as one more seta representing transformed G3 claw. Claws G2 and z1 subequally long, about 1.06 times longer than first endopodal segment. Claw G1 short and 3.4 times longer than terminal segment. Claw G3 also short and as long as terminal segment. Setae z2 and z3 missing. Terminal segment with long GM claw (0.95 times as long as first endopodal segment) and short $\mathrm{Gm}$ claw (2.5 times as long as terminal segment). L ratio of three endopodal segments $7: 4.1: 1$.

Md (Fig. 37) with well developed coxa; palp four-segmented. First segment with one plumose seta (S1; seta S2 not observed) and two smooth setae (short alpha seta and one long seta) on inner edge. Second segment with two short setae on outer edge and $3+2$ setae in bunch on inner edge. Following segment with two setae externo-medially (one almost reaching distal end of terminal claw, other just exceeding distal end of penultimate segment); gamma seta externo-distally (slightly exceeding distal end of terminal segment); and three setae interno-medially to interno-distally. Terminal segment with fused and distally pappose claw, one strong seta on outer edge, and two weaker setae on inner edge. L ratio of three distal segments $1: 2.2: 1.1$.

Mxl palp (Fig. 38) with square to trapezoidal terminal segment bearing two claw-like and four thin setae. Penultimate segment of same appendage with four pappose seta. Claws on third endite plumose.

Rake-like organ (Fig. 39) with about 10 teeth.

Prehensile palps (Figs 41, 42) almost symmetrical (left one with slightly thinner finger), both with elongated fingers and long, thin subapical structures.

T2 five-segmented (Fig. 44). Basal segment without seta, first endopodal segment with one seta (reaching middle of following segment). Second endopodal segment with one seta, penultimate segment with two setae. Terminal segment with two distal setae and claw. Claw distally serrated and as long as three distal-most segments combined.

T3 five-segmented (Fig. 45). Basal segment with d1, d2, and dp setae. Also, all other endopodal setae present. $L$ ratio of three distal setae $1: 2: 7.2$. Seta Th3 with two lateral spines.

Furca (Fig. 46) with both anterior and posterior setae developed. Posterior seta very short and not reaching distal end of posterior margin. Also, both claws well developed and with well developed spines. L ratio of anterior margin and anterior and posterior claws $2.26: 1.63: 1$.

Hemipenis (Fig. 40) with triangular "a" lobe (rounded distal margin). Lobe " $b$ " with acute, well sclerotized, more medially positioned part, as well as rounded and more dorsally positioned part. Lobe " $h$ " double-folded and with widely rounded distal margin. M process (g) rounded, well sclerotized proximally, but distally only on outer margins. Same process protruding between lobes. Zenker's organ with 

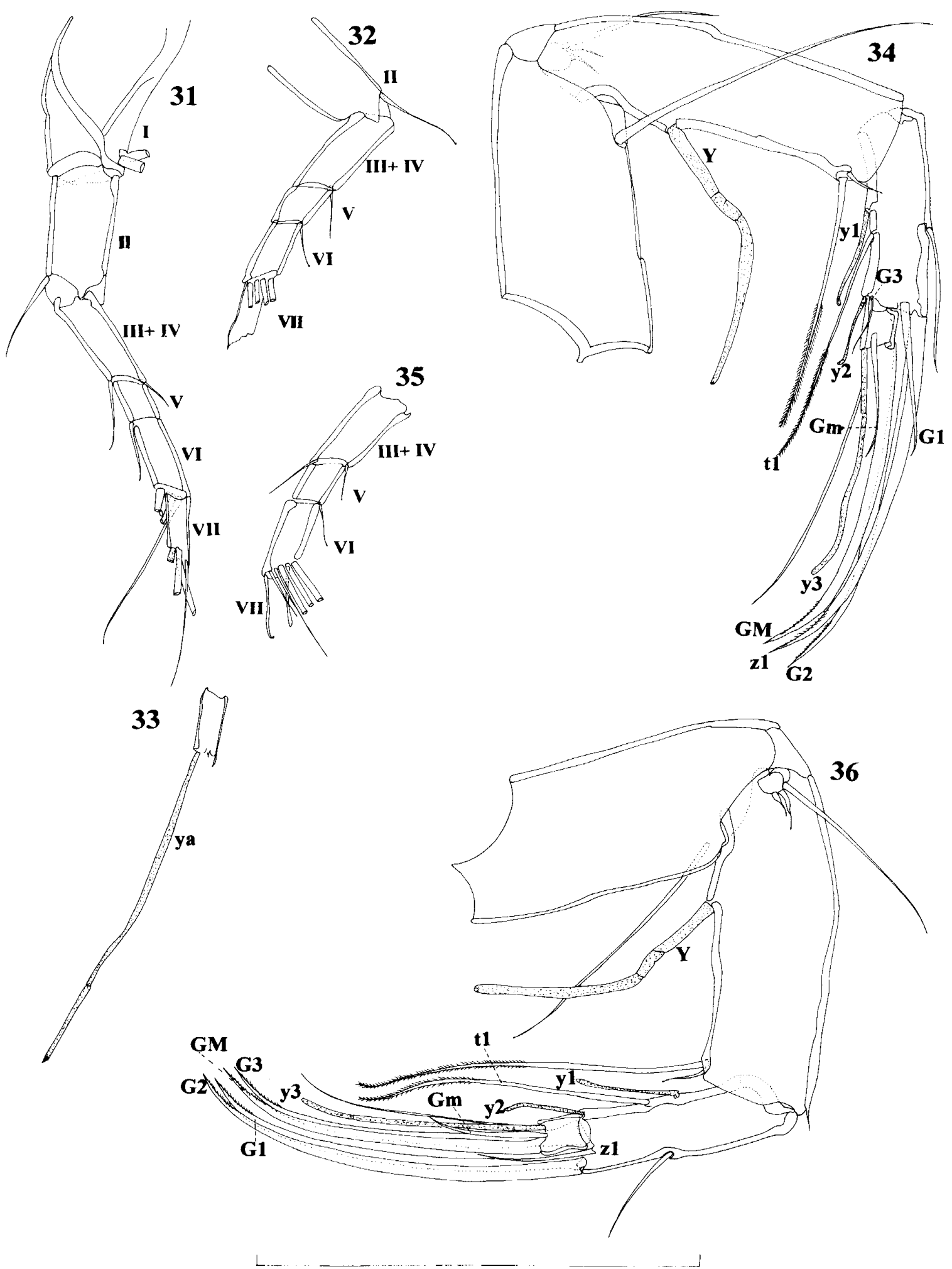

Figs 31-36. Meridiescandona facies n. gen., n. sp. 31-34, holotype male (L=0.546 mm); 35, 36, allotype female $(\mathrm{L}=0.558 \mathrm{~mm}) .31, \mathrm{Al} ; 32, \mathrm{Al}$, first segment not shown; 33, terminal segment of A1 with aesthetasc; 34, A2; 35, A1, frist and second segments not shown; 36, A2. Setae labelled in 33,34 , and 36 ; segments numbered in 31,32 , and 35 . Scale $=0.1 \mathrm{~mm}$. 


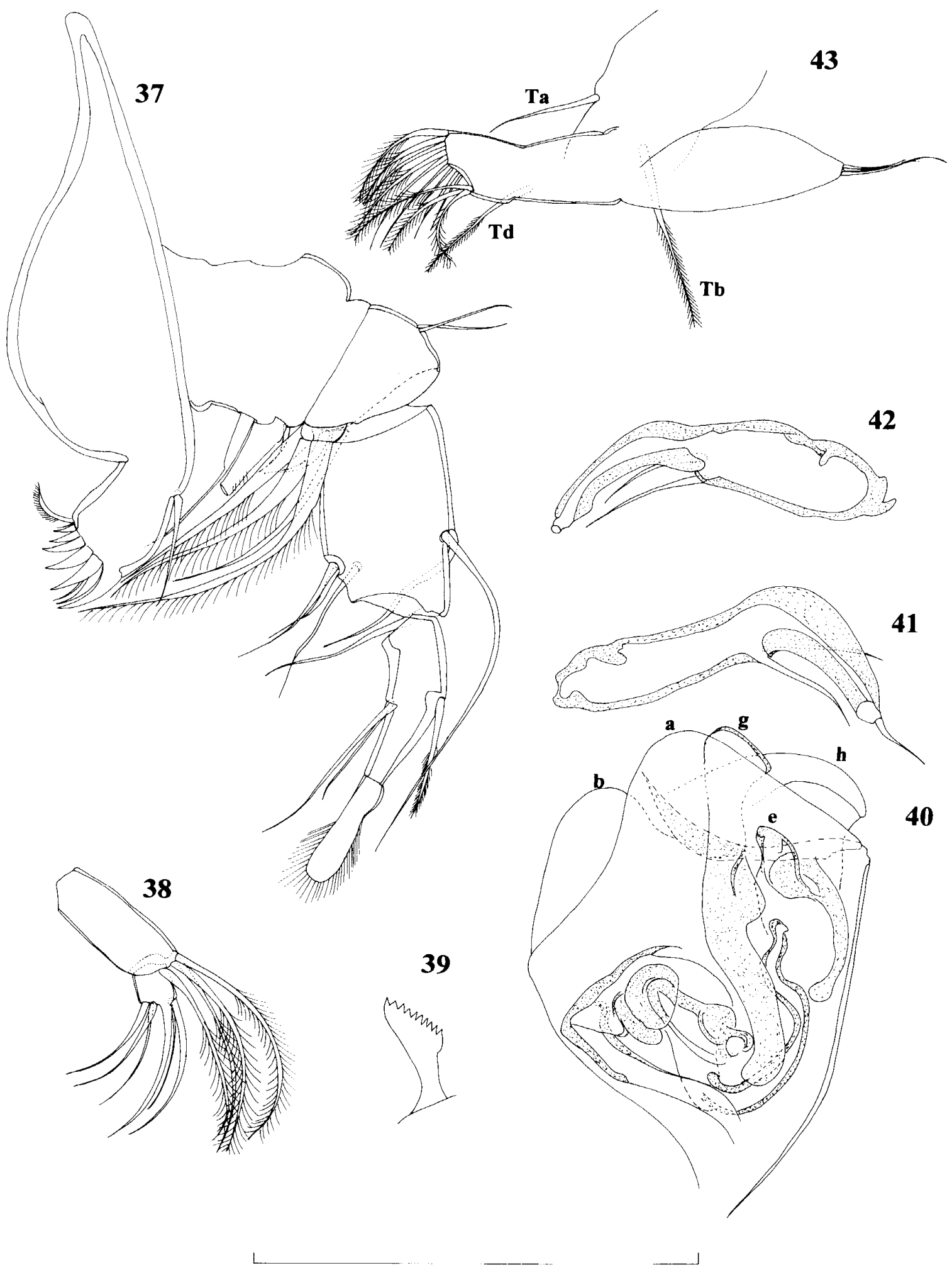

Figs 37-43. Meridiescandona facies n. gen., n. sp. 37-42, holotype male (L=0.546 mm); 43, allotype female $(\mathrm{L}=0.558 \mathrm{~mm}$ ). 37 , Md; 38, Mxl palp; 39, Rake-like organ; 40, hemipenis; 41, right prehensile palp; 42, left prehensile palp; 43, T1. Setae labelled in 43, lobes labelled in 40 . Scale $=0.1 \mathrm{~mm}$. 


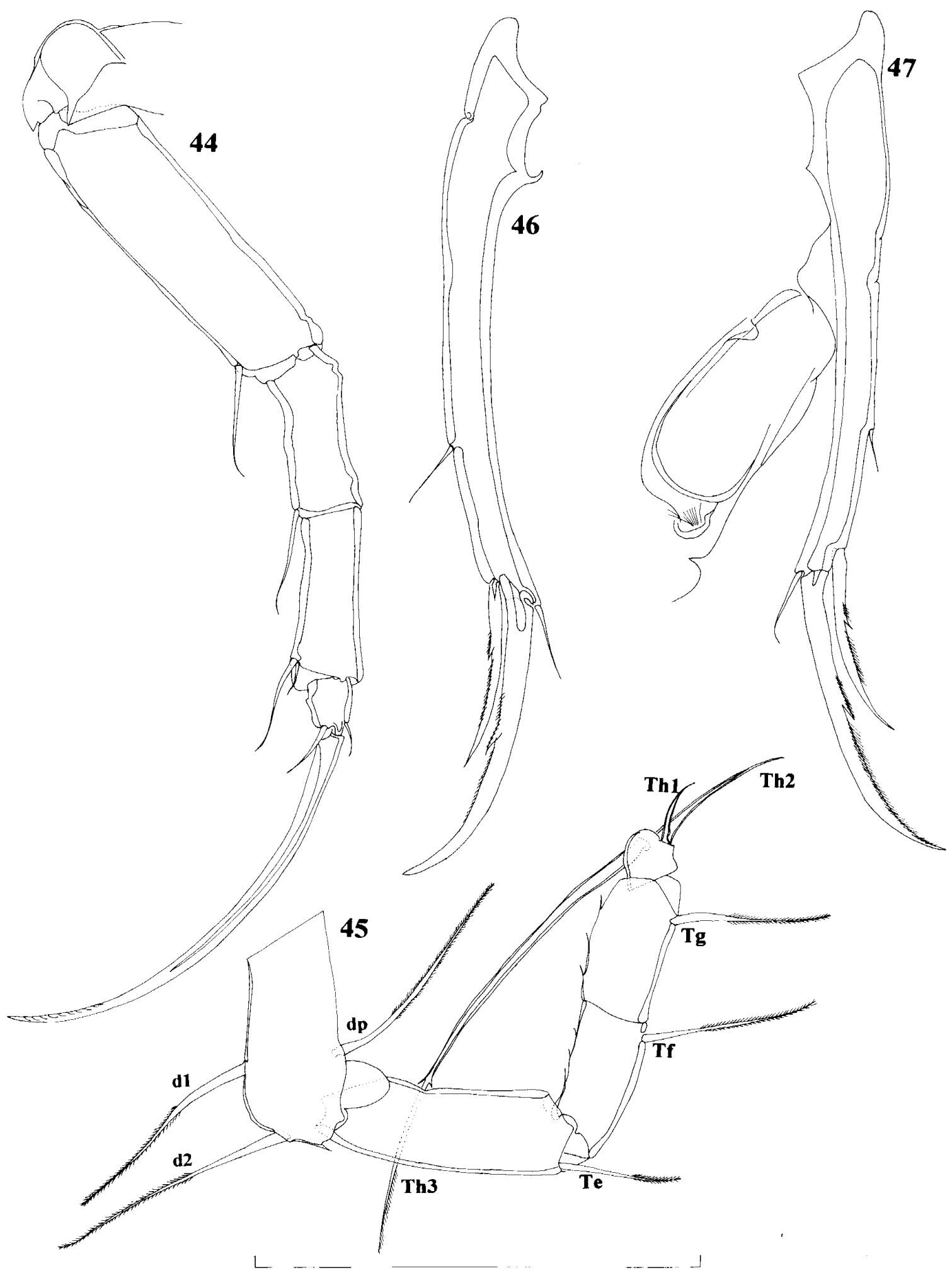

Figs 44 47. Meridiescandona facies n. gen., n. sp. 44-46, holotype male ( $\mathrm{L}=0.546 \mathrm{~mm}) ; 47$, allotype female $(\mathrm{L}=0.558 \mathrm{~mm}) .44, \mathrm{~T} 2 ; 45, \mathrm{~T} 3 ; 46, \mathrm{Fu} ; 47, \mathrm{Fu}$ with genital lobe. Setae labelled in 45 . Scale $=0.1 \mathrm{~mm}$. 
$5+2$ rows of spines.

Allotype (female, $\mathrm{L}=0.558 \mathrm{~mm}$ ). Carapace (Fig. 29) with dorsal margin more inclined towards posterior margin than in male, causing narrower appearance of posterior end. Greatest $\mathrm{H}$ on both valves equal to $48.9 \%$ of L, greatest W (Fig. 30) $29.2 \%$ of $\mathrm{L}$.

A1 (Fig. 35) with penultimate segment carrying three long and two short setae.

A2 (Fig. 36) with three long claws (G1, G2, and G3), and only one z1 seta on penultimate segment. Long claws subequally long and as long as first endopodal segment, while z1 2.4 times longer than terminal segment. As in male, only one tseta present. Terminal segment with one long GM claw (0.92 times as long as first endopodal segment), and short $\mathrm{Gm}$ claw (2.3 times longer than terminal segment). $\mathrm{L}$ ratio of endopodal segments $6.8: 3.6: 1$.

Length ratio of three apical setae on endopodite T1 (Fig. 43) $1: 1.2: 1.6$. T1 also with one Ta seta, and Tb and Td setae. Number of setae on exopodite not observed.

Genital lobe (Fig. 47) rounded, with several folds. Both claws of furca with well developed spines. $\mathrm{L}$ ratio of anterior margin and anterior and posterior claws 2.2 : $1.7: 1$.

All other appendages, Md, Mxl, T2, and T3, as in male.

Variability. In the holotype male one antennula (Fig. 32) has only one distal seta on the distal end of the third segment. Also, neither of the male's antennulae has two short setae on the distal end of the penultimate segment (beside three long setae) as is observed in one female's antennula (Fig. 35). It is worth noticing that other antennula of the same female carries only two long and two short setae on the penultimate segment.

Etymology. The specific name is a Latin noun facies (gender feminine) meaning face.

Remarks. The two new species are closely related, and their main differential features are as follows: 1) In Meridiescandona lucerna the valves are ornamented with reticular patterns, while in $M$. facies the ornamentation consists of small dots distributed linearly. 2) The outer margin at the anterior end in the type species is notched, but in the other species smooth. 3) Aesthetasc y1 is longer in $M$. facies (exceeds distal margin of penultimate segment), and shorter in $M$. lucerna (not reaching distal margin of same segment). 4) The anterior seta on the penultimate segment of A2 is very short in $M$. lucerna (not reaching distal margin of penultimate segment), and much longer in $M$. facies (far exceeding same distal margin). 5) The rake-like organ has more teeth in $M$. lucerna (about 19) than in $M$. facies (about 10). 6) The posterior furcal seta is much longer in the type species (reaching distal end of anterior margin) than in the other species (reaching only halfway from its origin to distal end of posterior margin). 7) The length ratio of the anterior and posterior furcal claws in $M$. lucerna is $1.3: 1$, but in $M$. facies $1.65: 1$. 8) The "M" process protrudes between the lobes of the hemipenis in $M$. facies, while it is enclosed in $M$. lucerna.

Genus Deminutiocandona n. gen.

Type species: Deminutiocandona mica n. sp. 
Diagnosis. Carapace subtriangular and smooth. LV overlapping RV on all free margins. Antennula five-segmented; fourth and fifth, as well as sixth and seventh segments being fused. Second antenna with male sexual bristles. Mandibular palp four-segmented. Second segment without any setae on outer edge, with bunch of $3+2$ setae on inner edge. Penultimate segment with two setae externo-medially, one externo-distally, and three interno-medially to interno-distally. Terminal segment with fused claw. L:W ratio of terminal segment less than $2: 1$. Terminal segment of maxillular palp square-shaped. T1 without any protopodal setae. Exopodite of same appendage with two rays. Prehensile palps symmetrical with elongated, hook-like fingers and long subterminal structures. T2 five-segmented and without seta on basal segment. Setae on penultimate segment short. T3 five segmented. Basal segment with dp and dl setae, seta d2 absent. Second and third endopodal segments without any setae, but penultimate segment with very short $\mathrm{Tg}$ seta. Terminal segment with two short (Th1, Th2) and one long setae (Th3). Seta Th3 without subterminal spines. Furca with all claws and setae present, or without anterior claw. Genital lobe rounded and without appendages. Lobe "a" of hemipenis subtriangular, extended dorsally. Lobe " $b$ " flat and without additional structures. Lobe " $h$ " rounded and with some sclerotized structures ventrally. Central chitinized part $(\mathrm{g})$ very weakly sclerotized, being flat and hardly distinguishable. Zenker's organ with $4+2$ rows of spines.

Etymology. The genus name is composed of two words: deminutio, which is a Latin noun (gender feminine) meaning diminution, and the genus name Candona (gender feminine).

\section{Deminutiocandona mica $\mathrm{n} . \mathrm{sp}$.}

(Figs 48-67)

Material. Holotype (male on slide, WAM C28420), allotype (female on slide, WAM C28421), and six paratypes (one male on slide, WAM C28422; one male and four juveniles in alcohol, WAM C28423) from Weeli Wolli Spring (Bou-Rouche pump), Pilbara Region, Western Australia, $22^{\circ} 55^{\prime} \mathrm{S}, 119^{\circ} 11^{\prime} \mathrm{E}, 16$ November 1998 , collector S. M. Eberhard (BES: 3594).

Description. Holotype (male, $\mathrm{L}=0.319 \mathrm{~mm}$ ). Carapace subtriangular in lateral view. $\mathrm{L}$ of $\mathrm{LV}=0.319 \mathrm{~mm}$ (Fig. 48); $\mathrm{L}$ of $\mathrm{RV}=0.299 \mathrm{~mm}$. Greatest $\mathrm{H}$ on both valves slightly behind midlength, equal to $47 \%$ of L. Dorsal margin almost evenly rounded and sloping equally and gradually towards both anterior and posterior margins, these being rounded, posterior one slightly narrower. Ventral margin slightly convex in middle. Valve surface covered with long, sparse hairs, especially on posterior end. Surface smooth. Anterior marginal zone $26.6 \%$ of total L, while posterior zone $12.9 \%$ of total L. Fused zone narrow with short, dense pore canals, not distinguishable posteriorly. Selvage not visible. Flange developed on LV only ventrally. In dorsal view (Fig. 49) anterior end slightly cuneiform, posterior end rounded. LV overlapping RV clearly on all free margins. Greatest W not measured.

A1 (Fig. 55) five-segmented. First segment with one seta antero-proximally (not shown in Fig. 55), without any seta antero-distally, and with two long setae posteriorly; second segment with one seta anteriorly (reaching almost middle of penultimate segment); third segment with two setae distally (both reaching distal margin 

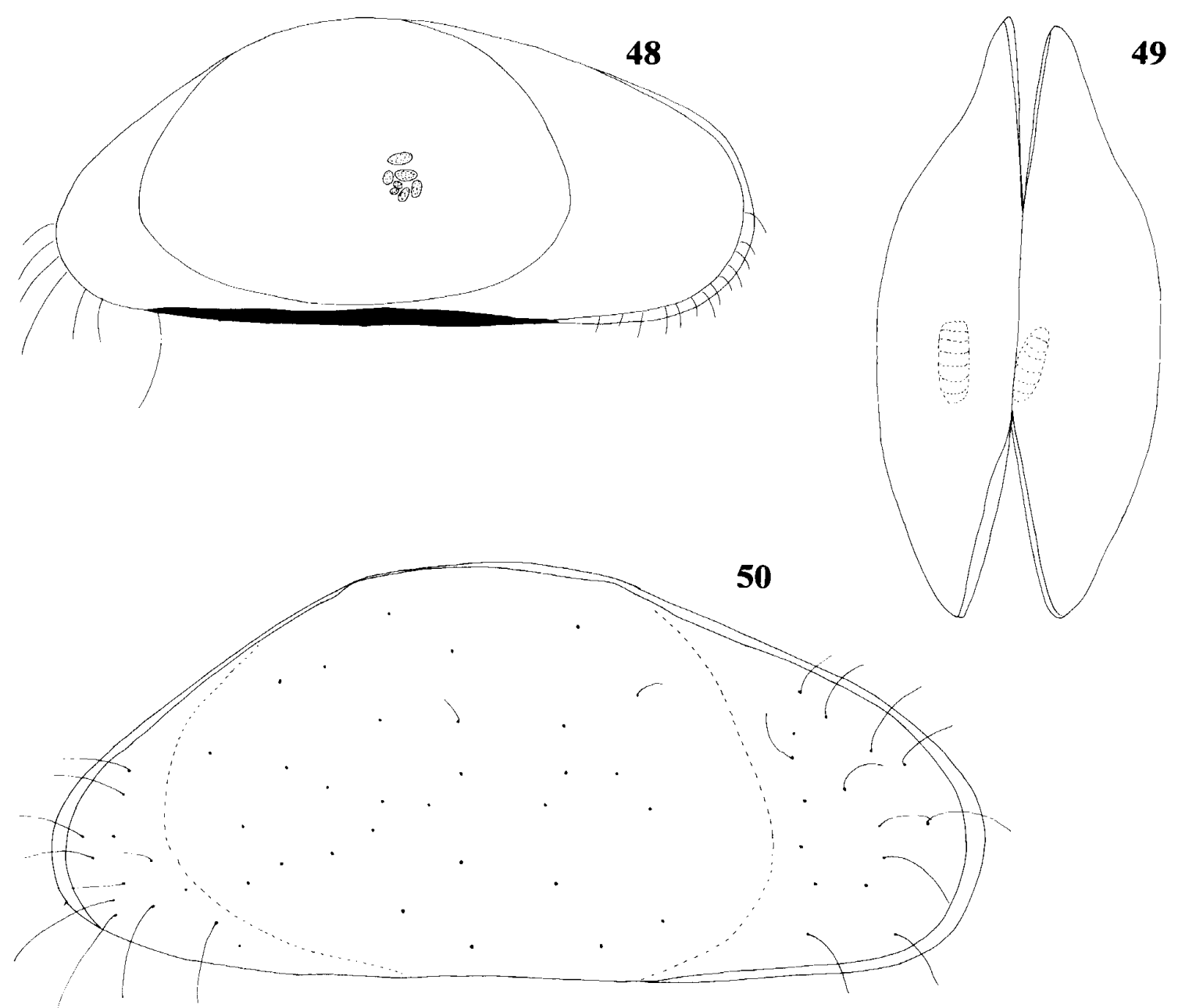

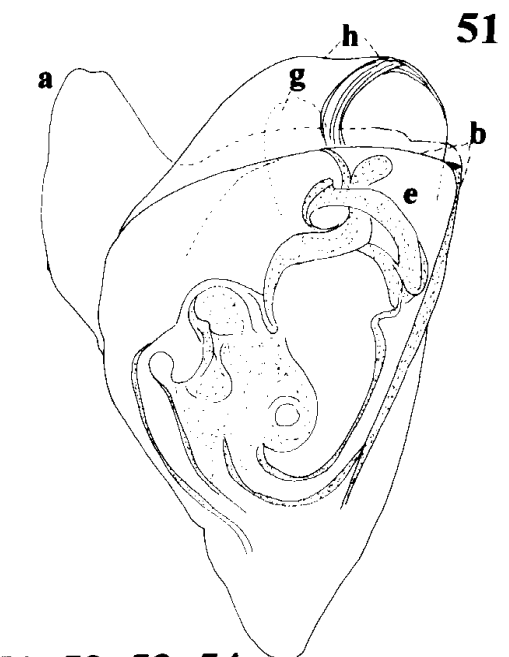

$51,52,53,54$
52
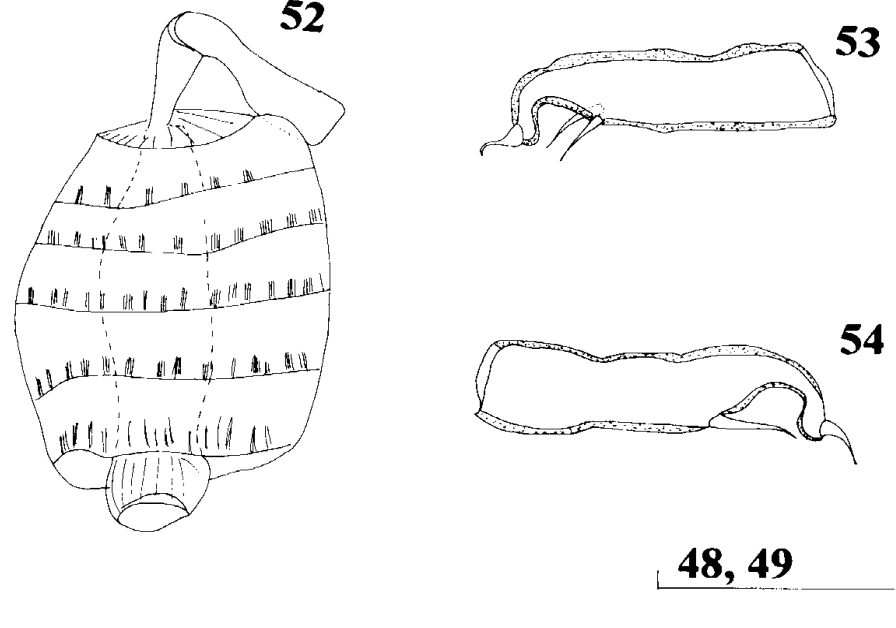

48,49

Figs 48-54. Deminutiocandona mica n. gen., n. sp. 48, 49, 51-54, holotype male (L=0.319 mm); 50 , paratype male $(\mathrm{L}=0.305 \mathrm{~mm}) .48, \mathrm{LV}$, internal view; 49 , carapace, dorsal view; 50 , carapace, external view; 51, hemipenis; 52 , Zenker's organ; 53, left prehensile palp; 54, right prehensile palp. Lobes labelled in 51 . Scale $=0.1 \mathrm{~mm}$. 
of following segment); fourth segment with two setae distally (exceeding distal end of terminal segment); terminal segment with two long and one short setae (short one about 1.4 times as long as terminal segment) and aesthetasc (ya) about 2.5 times as long as terminal segment. $L$ ratio of three distal segments $1: 2: 2$.

A2 (Fig. 56) five-segmented and with male bristles. Exopodite plate with two short and one longer setae (about 12.5 times longer than shortest one). Aesthetasc Y 1.3 times longer than first endopodal segment; aesthetascs y1 and y2 not observed; y3 2.5 times longer than first endopodal segment. Penultimate segment subdivided with two male sexual bristles representing transformed $t 2$ and $t 3$ setae. Anterior seta present and exceeding distal end of terminal segment. Penultimate segment also with three distal claws (G1, G2, and z1) and z3 seta. Claw G3 and z2 seta absent. Claws G2 and z1 subequally long, about 1.7 times longer than first endopodal segment. Claw G1 short and 4.9 times longer than terminal segment, while $\mathrm{z} 3$ as long as that segment. Terminal segment with long GM claw (1.4 times as long as first endopodal segment) and short $\mathrm{Gm}$ claw (3.8 times as long as terminal segment). L ratio of four endopodal segments $5.2: 2.2: 1.5: 1$.

Md with well developed coxa (Fig. 63); palp four-segmented (Fig. 62). First segment with two plumose setae (long S1 and short S2) and two smooth setae (short alpha seta and one long seta) on inner edge. Second segment without any seta on outer edge, with $3+2$ setae in bunch on inner edge. Beta seta long (almost as long as all corresponding setae). Following segment with two setae externo-medially (one reaching middle of terminal claw, other reaching middle of penultimate segment), gamma seta externo-distally (exceeding middle of terminal claw), and three setae interno-medially to interno-distally. Terminal segment with fused and distally plumose claw, one thicker seta on outer edge, and one thinner seta on inner edge. $\mathrm{L}$ ratio of three distal segments $1.5: 2.2: 1$.

Mxl palp (Fig. 58) with square, extremely small terminal segment bearing two claw-like and three thin setae. Penultimate segment of same appendage with three setae.

Rake-like organ (Fig. 57) with numerous small denticles.

Prehensile palps (Figs 53, 54) almost symmetrical, hook-shaped. On right prehensile palp only one, robust, subterminal structure observed.

T2 five-segmented (Fig. 64). Basal and first endopodal segments without setae. Third segment with one seta, penultimate segment with two short setae. Terminal segment with two distal setae and claw, latter not serrated and 1.4 times as long as three distal-most segments combined.

T3 five-segmented (Fig. 65). Basal segment with d1 and dp setae, d2 seta absent. First and second endopodal segments without any setae, while Tg seta small. L ratio of three distal setae $1: 2.7: 13.7$. Seta Th3 without lateral spines.

Furca (Fig. 66) without anterior claw on each ramus. Other claw and both posterior and anterior setae developed. $\mathrm{L}$ ratio of anterior margin and posterior claw $1.4: 1$.

Hemipenis (Fig. 51) with triangular, dorsally protruded "a" lobe, and flat lobe " $b$ " with no additional structures as in Meridiescandona. Lobe " $h$ " wide and in its dorsal part apparently fused with lobe "b", ventral part with several sclerotized striae. $M$ process (g) very weakly sclerotized and difficult to observe. Zenker's organ (Fig. 52) with $4+2$ rows of spines.

Allotype (female). Structure and L of carapace not observed due to complete de- 


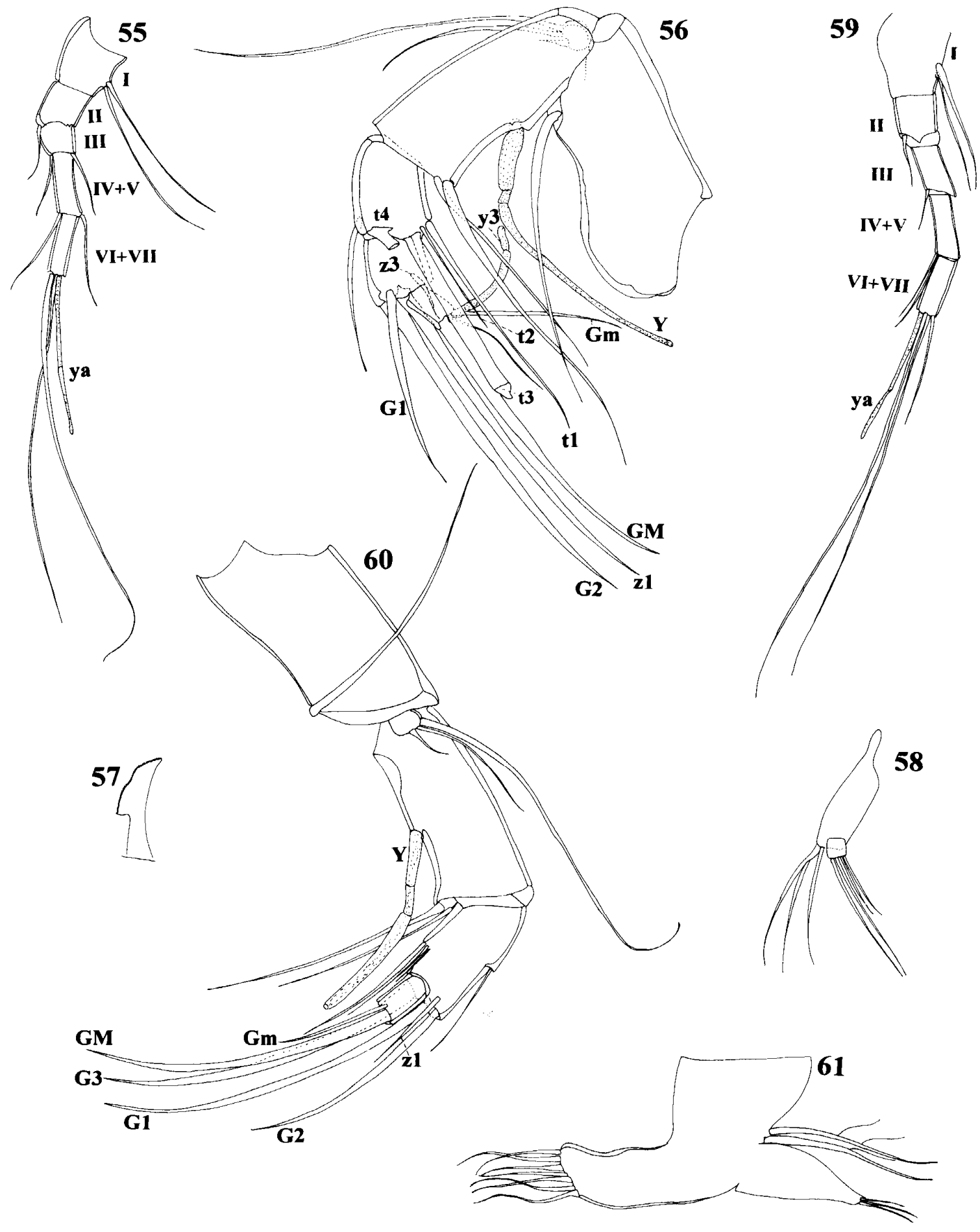

Figs 55-61. Deminutiocandona mica n. gen., n. sp. 55-58, holotype male (L=0.319 mm); 59-61, allotype female. 55, A1; 56, A2; 57, Rake-like organ; 58, Mxl palp; 59, A1; 60, A2; 61, T1. Setae labelled in 56 and 60 ; segments numbered in 55 and 59 . Scale $=0.1 \mathrm{~mm}$. 

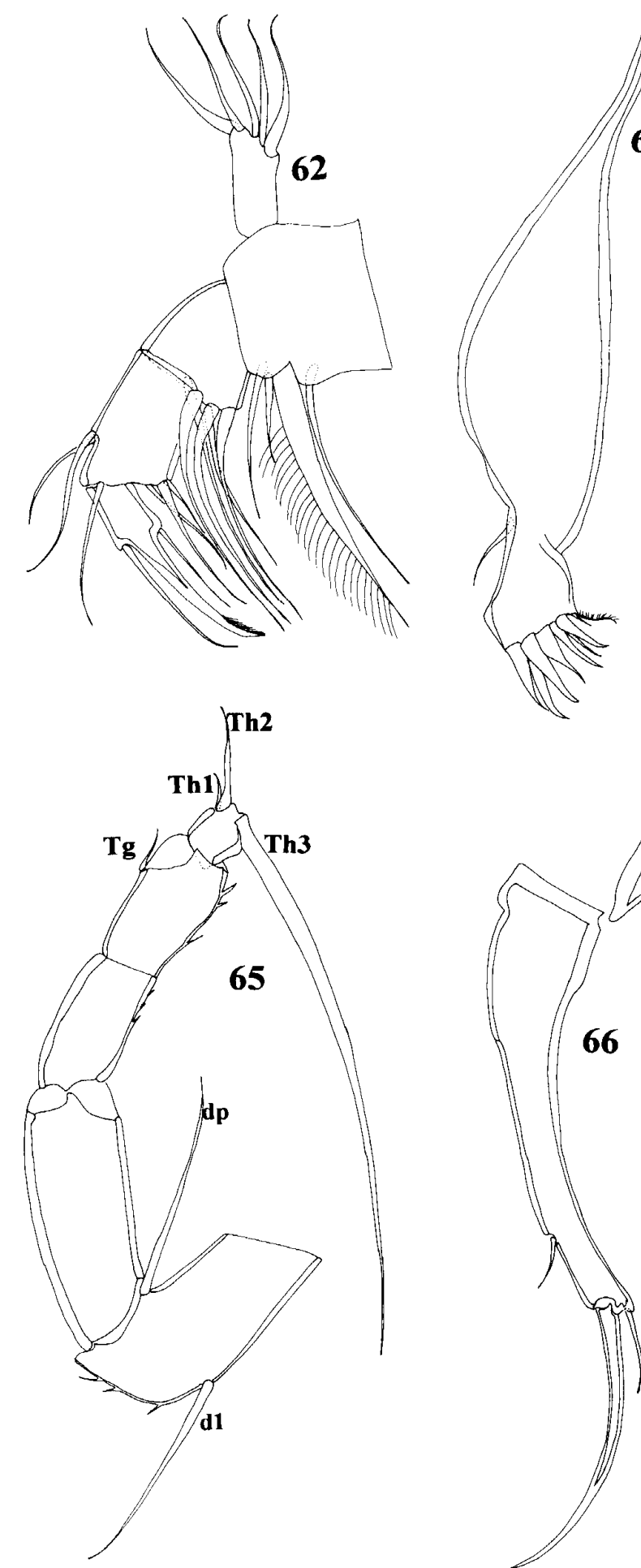

63

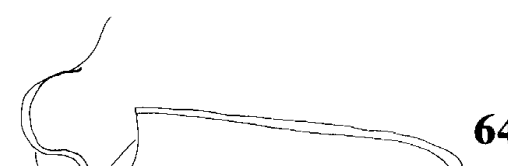

64

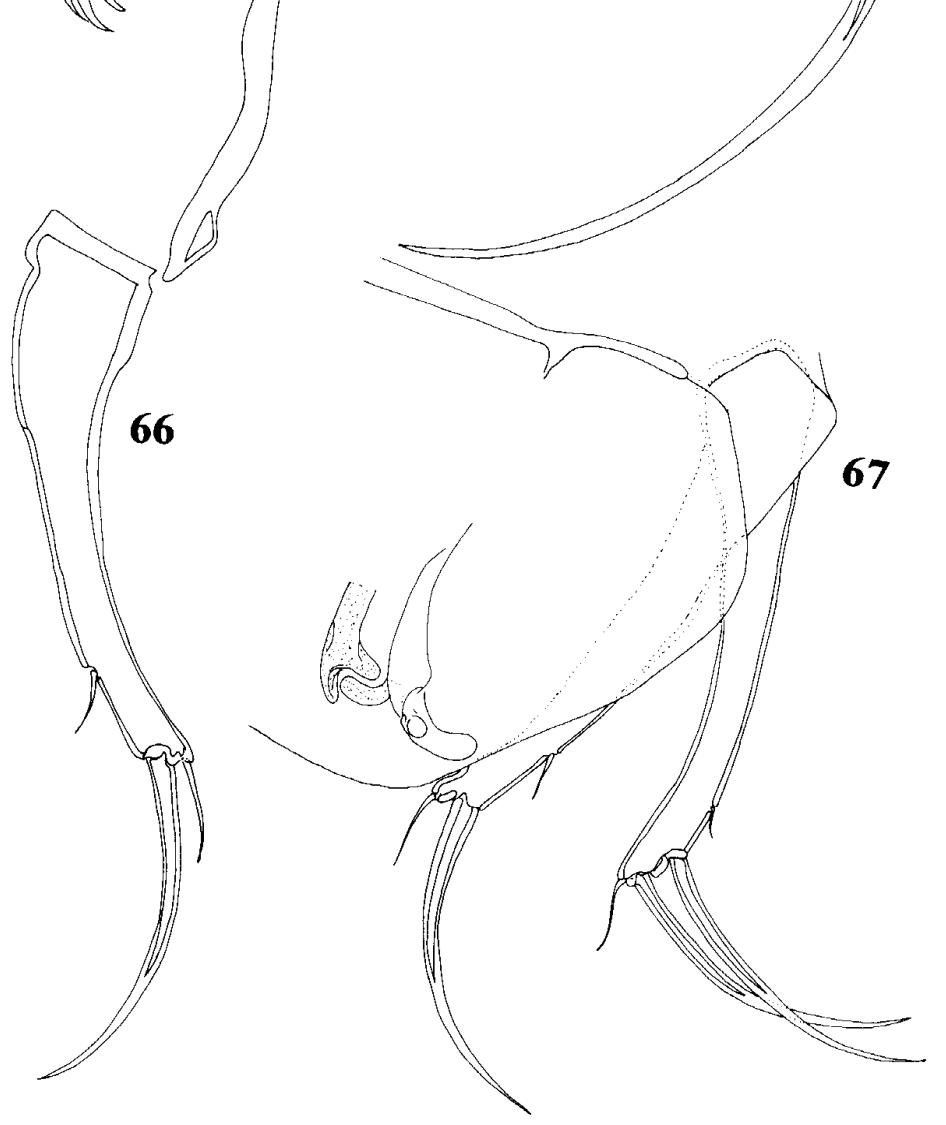

Figs 62-67. Deminutiocandona mica n. gen., n. sp. 62-66, holotype male (L=0.319 mm); 67, allotype female. 62, Md palp; 63, Md coxa; 64, T2; 65, T3; 66, Fu; 67, both furcae with genital lobes. Setae labelled in 65 . Scale $=0.1 \mathrm{~mm}$. 
calcification of valves.

A1 (Fig. 59) lacking posterior setae on third, fourth, and fifth segments and with two setae antero-distally on fourth segment. Length ratio of three distal segments $1: 1.3: 1$.

A2 (Fig. 60) four-segmented with three claws (G1, G2, and G3), and only z1 seta on penultimate segment. Claws G1 and G3 subequally long and 1.6 times longer than first endopodal segment, while G2 about as long as first endopodal segment. Seta z1 1.9 times longer than terminal segment. Three t-seta observed. Terminal segment with one long GM claw (1.4 times as long as first endopodal segment) and short $\mathrm{Gm}$ claw (2.3 times longer than terminal segment). Aesthetasc Y only as long as first endopodal segment. L ratio of endopodal segments $4.3: 2.6: 1$.

Length ratios of three apical setae on endopodite T1 1:1.3:1.3 (Fig. 61). T1 without any protopodal seta and with two rays on exopodite.

Genital lobe (Fig. 67) rounded. On one furcal ramus both claws well developed, with $\mathrm{L}$ ratio of anterior margin and anterior and posterior claws 1.73:1:1.1 (posterior claw slightly longer than anterior one). Other furcal ramus as in male, anterior claw missing. Length ratio of anterior margin and posterior claw 1.6:1.

All other appendages (Md, Mxl, T2, and T3) as in male.

Variability. No other variability besides in the appearance of the two furcal ramus in the allotype female (described above) was noticed in this species.

Etymology. The specific name is a Latin noun mica (gender feminine), meaning crumb.

\section{Discussion}

The following genera of Candoninae are known only from Australian subterranean waters: Acandona Karanovic, 2003; Humphreyscandona Karanovic and Marmonier, 2003; Pilbaracandona Karanovic and Marmonier, 2003; and Notacandona Karanovic and Marmonier, 2003 (Karanovic 2003; Karanovic and Marmonier 2003). Deminutiocandona n. gen. differs from all these, and from Meridiescandona n. gen., in having $4+2$ rows of spines on the Zenker's organ (rather than $5+2$ rows of spines). In the subfamily Candoninae there are never more than seven rows of spines on the Zenker's organ, and spine reduction is rare in this subfamily, being found only in Schellencandona Meisch, 1996, Danielocandona Broodbakker, 1983, Trajancandona Karanovic, 1999, and Baicalocandona Mazepova, 1976 (Broodbakker 1983; Mazepova 1990; Meisch 1996; Karanovic 1999b). In the genus Namibcypris the number of spines is unknown; they were not developed in the holotype male (see Martens 1992). In the genera Deminutiocandona, Shellencandona, Danielocandona, and Trajancandona the reduction of spine rows can be attributed to the reduction in body size, as postulated by Meisch (1996); however, this is not true for Baicalocandona. The number of rows is a very important generic feature in the subfamily Candoninae, but, as with all the other male characteristics (see further discussion), it must be treated with caution because many species are known only from females. Notwithstanding this fact, the number of spine rows in the family Candonidae is extremely stable in comparison with other Cypridoidea, in which this character can be so variable that it is not even used in the diagnosis of most genera (see Meisch 2000). 
Another feature that clearly separates Deminutiocandona from Meridiescandona, Humphreyscandona, Pilbaracandona, and Notacandona is the absence of a well sclerotized part on the " $b$ " lobe of the hemipenis. This lobe is flat in Deminutiocandona and without any protrusions (in contrast to the above Australian genera) and it appears to be dorsally fused with lobe "h". Similarly, Acandona does not have sclerotized parts on the "b" lobe (Karanovic 2003), but there are more differences than similarities (see below) between those two genera and they cannot be confused. This well sclerotized part of lobe " $b$ " is not reported in any other Candoninae, and its appearance and position in relation to the other parts of the hemipenis is quite peculiar in the Australian genera. The same is true of the sclerotized structure, or part "g", which protrudes between the lobes in the species Meridiescandona facies and all species of the genus Humphreyscandona. This part is easily detachable from the other parts of the hemipenis in genera such as Candona s. lat. I was unable to do the same with the Australian genera, both because of their very small size and because this process is not well sclerified throughout. A flat and very weakly sclerotized "g" part is found in most of genera of Candoninae, as in Deminutiocandona. The morphology of the hemipenis is very diverse within the subfamily Candoninae but quite similar among congeners. For this reason, genera such as Eucandona which include species with disparate hemipenis morphology, are in need of revision.

Another unique feature of Deminutiocandona, so far unknown in any other genus of Candoninae (including the Australian endemics), is the reduction of the anterior furcal claw, as found in both the males observed. The validity of this character for sexual dimorphism remains to be confirmed, however. Only a single female has been examined, which had one furcal ramus armed as in males, but the other with all furcal claws developed. Within the subfamily Candoninae, as well as in all other Cypridoidea, the morphology of the furca is one of the most important generic features. All species of the genera Candonopsis Vávra, 1891, Caribecandona Broodbakker, 1983, and Cubacandona Broodbakker, 1983 lack the posterior furcal seta (Vávra 1891; Broodbakker 1983), whereas the genera Caribecandona, Phreatocandona Danielopol, 1978, Indocandona Gupta, 1984, Meischcandona Karanovic, 2001, Humphreyscandona, and Pilbaracandona have a reduced posterior furcal claw (Broodbakker 1983; Danielopol 1978; Gupta 1984, Karanovic 2001; Karanovic and Marmonier 2003). Namibcypris and Danielocandona have a furca with a very short ramus and only the anterior claw present, which is completely fused with the ramus. Because of this level of reduction they are included in the same tribe Namibcypridini (see Martens 1992). This regularity even at the level of the superfamily raises considerable difficulties in the taxonomy of the Australian ostracod fauna. In addition to Deminutiocandona mica, described herein, two other species have been found in Australia in which the morphology of the furca is aberrant for their nominal genera: Humphreyscandona woutersi Karanovic and Marmonier, 2003 and Candonopsis westaustraliensis Karanovic and Marmonier, 2002. The former lacks the anterior furcal seta (which is present in the other four species of the genus), while the latter has a reduced posterior furcal claw, otherwise never recorded in the genus. Despite these differences they were not described in separate genera because of the very strong affinities with their congeners in all other morphological features, and the irregularities were interpreted as convergences (Karanovic and Marmonier 2003). In Meridiescandona both furcal claws and both 
furcal setae are developed, and both species have a robust spine on their claws as is found in four of the five species of the genus Humphreyscandona and in many species of Candonopsis. These characters have taxonomic importance only at the specific level, and even then must be treated with caution, because they are highly variable in the genus Candonopsis (see Karanovic and Marmonier 2002).

The number of setae on the inner side of the second segment of the mandibular palp has been considered an important feature in the taxonomy of the genus Candona s. lat. (Müller 1900; Klie 1938; Bronstein 1947; Sywula 1974). Candona s. str., Pseudocandona, and Eucandona Daday, 1900 sensu Petkovski and Karanovic (2000) are the only genera of Candoninae with a variable number of setae on the inner side of the second segment of the mandibular palp. Indeed, these genera are divided into several species-groups according to this character. The appearance of the gamma seta on the penultimate segment of the mandibular palp has been used to discriminate the two large genera Eucandona sensu Petkovski and Karanovic (2000) and Candona s. str. Namely, this seta is plumose in Candona but smooth in Eucandona. These characters will not be dealt with here, as they are part of a more detailed revision. Here we just draw attention to the fact that some closely related species are spread across these two genera on the basis of the appearance of the gamma seta, despite having great similarities in the majority of other morphological characters. The Australian genera have such a different chaetotaxy of this appendage that it is easy to distinguish them according to this character alone, but they all have $3+2$ setae in a bunch on the inner edge of the second segment. In Deminutiocandona and Notacandona the outer edge of the second segment lacks any seta, while Meridiescandona, Humphreysacandona, and Acandona have two setae, and Pilbaracandona has only one seta in that position. Setae on the outer edge are also absent in Danielocandona, Namibcypris, Phreatocandona, and Trajancandona, while Nannocandona Ekman, 1914 has only one external seta on the outer edge (see Mamonier and Danielopol 1988). It appears that all the other genera of Candoninae always have two setae in the same position.

In most members of the family Candonidae the male antenna is furnished with sexual bristles that are actually transformed " $t$ " setae. In the subfamily Candoninae there are several examples of genera in which these structures are present in one species, but absent in another (Pseudocandona, Trapezicandona Shornikov, 1969, Baicalocandona). The taxonomic importance of this character at the generic level is discussed by Karanovic (2000). Here I will just mention that Deminutiocandona and Acandona are the only Australian genera in which these setae are developed, while in all the other Australian genera males lack sexual bristles. The antenna plays a very important role in locomotion, chemoreception (Danielopol 1973), and especially copulation (Horne et al. 1998), and $Y$ is very long in all the Australian genera, especially in the genus Deminutiocandona, where this aesthetasc is 1.3 times longer than the first endopodal segment.

The three new species described here are similar to the majority of Candoninae, in which the exopodite of the antenna consists of a plate with two short and one long setae. In genera such as Phreatocandona and Trajancandona the exopodite consists of three short setae (Danielopol 1978; Karanovic 1999b), whereas Terrestricandona Danielopol and Betsch, 1980 and Danielocandona have two setae (Danielopol and Betsch 1980), and Namibcypris and Nannocandona have only one seta (Martens 1992; Marmonier and Danielopol 1988). In one of the species of the 
genus Humphreyscandona the exopodite consists of three short setae, while four other species have two short and one long setae (Karanovic and Marmonier 2003). Such examples of not very closely related genera having the same type of antennal exopodite, together with the presence of a single species in one genus with an atypical exopodite, suggest that this character alone is in itself insufficient to distinguish genera and may be convergent in different lineages.

The antennula in most Cyprididae comprises seven segments. Among the Candoninae, 11 of the 24 described genera display a reduced number of antennular segments. The genera Terrestricandona, Caribecandona, Namibcypris, and Meridiescandona have six-segmented antennula (Danielopol and Betsch 1980; Broodbakker 1983; Martens 1992). Five-segmented antennulae are found in Nannocandona, Danielocandona, Meischcandona, Humphreyscandona, Pilbaracandona, and Notacandona (see Marmonier and Danielopol 1988; Broodbakker 1983; Karanovic 2001; Karanovic and Marmonier 2003). In the six-segmented antennulae the fusion occurs between the third and fourth segments (Meridiescandona and Caribecandona), whereas in the five-segmented antennulae the fusions lie between the third and fourth and between the fifth and sixth segments (in Humphreyscandona, Pilbaracandona, Notacandona, and Danielocandona), or between the third and fourth and the sixth and seventh segments (Nannocandona). Deminuticandona is the only genus displaying fusion between the fourth and fifth, and the sixth and seventh segments. In the genera Terrestricandona and Namibcypris there are no clear points of fusion.

The shapes of the carapaces in the two new genera are not distinct from those of the other Candoninae. A triangular carapace like that of Deminutiocandona mica is more often found in interstitial Candoninae (see Danielopol 1980) than is a rectangular carapace, like those of both Meridiescandona lucerna and $M$. facies. The latter two species both have carapace ornamentation patterns that are clearly noticeable even at low magnification, but the carapace is smooth, as in the genus Deminutiocandona. This is in contrast to other genera of the Australian Candoninae, in which all species have different extents of valve ornamentation, but it is always present (Karanovic and Marmonier 2003). Carapace ornamentation is more often found in Tertiary genera (see Krstic 1972; Krstic and Guan 2000) than in Recent ones, where it can be found in several species of one genus (such as Pseudocandona and Trapezicandona), or in all the species in a genus (like Baicalocandona).

In conclusion, Meridiescandona is easily distinguishable from the rest of the Candoninae by the combination of two main characters: a six-segmented antennula and having all furcal elements developed. It is very closely related to all the other Australian Candoninae, especially to Humphreyscandona, with which it shares a very similar hemipenis morphology. Deminutiocandona may be distinguished by the combination of a five-segmented antennula, reduction of the anterior furcal claw, and $4+2$ rows of spines on the Zenker's organ. The morphology of the hemipenis, the furca itself, and the fusion pattern of the antennular segments give this genus a separate position not only within the Australian genera but within the subfamily as a whole. 


\section{Acknowledgments}

This paper is a part of the project financed by an Australian Biological Resources Study (ABRS) Grant for the years 2002/2003.

\section{References}

Baird, W. 1845. Arrangements of the British Entomostraca, with a list of species particularly noticing those which have as yet been discovered within the bounds of the club. Transactions of the Berwickshire Naturalists Club 2 (74): 145-158.

Bradbury, J. H. and Williams, W. D. 1996a. Freshwater amphipods from Barrow Island, Western Australia. Records of the Australian Museum 48: 33-74.

Bradbury, J. H. and Williams, W. D. 1996b. Two new species of anchialine amphipod (Crustacea: Hadziidae: Liagoceradocus) from Western Australia. Records of the Western Australian Museum 17: 395-409.

Bradbury, J. H. and Williams, W. D. 1997a. Amphipod (Crustacea) diversity in underground waters in Australia: an Aladdin's Cave. Memoirs of Museum Victoria 56: 513-519.

Bradbury, J. H. and Williams, W. D. 1997b. The amphipod (Crustacea) stygofauna of Australia: description of new taxa (Melitidae, Neoniphargidae, Parametilidae), and a synopsis of known species. Records of the Australian Museum 49: 249-341.

Bronstein, Z. S. 1947. Ostracoda Presnykh Vod Fauna SSSR: Rakoobraznye 5 (1). Zoologicheskii Institut Akademii Nauk SSSR, Moskva, Leningrad, 339 pp.

Broodbakker, N. W. 1983. The subfamily Candoninae (Crustacea, Ostracoda) in the Western Indies. Bijdragen tot de Dierkunde 53: 287-326.

Broodbakker, N. W. and Danielopol, D. L. 1982. The chaetotaxy of Cypridacea (Crustacea, Ostracoda) limbs: proposal for a descriptive model. Bijdragen tot de Dierkunde 52: 103-120.

Bruce, N. L. and Humphreys, W. F. 1993. Haptolana pholeta sp. nov., the first subterranean flabelliferan isopod crustacean (Cirolanidae) from Australia. Invertebrate Taxonomy 7 : 875-884.

Danielopol, D. L. 1969. Recherches sur la morphologie de l'organe copulateur mâle chez quelques ostracodes du genre Candona Baird (fam. Cyprididae Baird). Pp. 136-153. In: Neale, J. W. (Ed.). The Taxonomy, Morphology and Ecology of Recent Ostracoda. Oliver \& Boyd, Edinburgh, 553 pp.

Danielopol, D. L. 1973. Sur la morphologie des aesthetascs chez quelques ostracodes hypogés de la sous-famille des Candoninae (Cyprididae, Podocopida). Annales de Spéléologie 28: 233-245.

Danielopol, D. L. 1978. Über Herkunft und Morphologie der europäischen Süsswasser-Ostracoden. Sitzungsberichte der Österreichischen Akademie der Wissenchaften, Mathematisch-Naturwissenschaftliche Klasse, Abteilung I 187: 1-162.

Danielopol, D. L. 1980. On the carapace shape of some European freshwater interstitial Candoninae (Ostracoda). Proceedings of the Biological Society of Washington 93: 743-756.

Danielopol, D. L., Baltanas, A. and Humphreys, W. F. 2000. Danielopolina kornickeri sp. n. (Ostracoda, Thaumatocypridoidea) from a Western Australian anchialine cave: morphology and evolution. Zoologica Scripta 29: 1-16.

Danielopol, D. L. and Betsch, J. M. 1980. Ostracodes terrestres de Madagascar: Systématique, origine, adaptations. Revue d'Écologie et de Biologie du Sol 17: 87-123.

De Laurentis, P., Pesce, G. L. and Humphreys, W. F. 1999. Copepods from ground waters of 
Western Australia, IV. Cyclopoids from basin and craton aquifers (Crustacea: Copepoda: Cyclopidae). Records of the Western Australian Museum 19: 243-257.

De Laurentis, P., Pesce, G. L. and Humphreys, W. F. 2001. Copepods from ground waters of Western Australia, VI. Cyclopidae (Crustacea: Copepoda) from Yilgarn Region and Swan Coastal Plain. Records of the Western Australian Museum 19: 243-257.

Gupta, L. P. 1984. Indocandona krishnakanti, gen. et sp. nov. (Crustacea: Ostracoda: Candonidae) from subterranean waters of Bihar, India. Records of the Zoological Survey of India 81: 291-298.

Harvey, M. S. 1998. Unusual new water mites (Acari: Hydracarina) from Australia, Part I. Records of the Western Australian Museum 19: 91-106.

Harvey, M. S., Gray, M. R., Hunt, G. S. and Lee, D. C. 1993. The cavernicolous Arachnida and Myriapoda of Cape Range, Western Australia. Records of the Western Australian Museum, Supplement (45): 129-144.

Horne, D. J., Danielopol, D. L. and Martens, K. 1998. Reproductive behaviour. Pp. 157-195. In: Martens, K. (Ed.). Sex and Parthenogenesis: Evolutionary Ecology of Reproductive Modes in Non-marine Ostracods. Backhuys Publishers, Leiden, $321 \mathrm{pp.}$

Humphreys, W. F. 1993a. Stygofauna in semi-arid tropical Western Australia: a Tethyan connection? Mémoires de Biospéologie 20: 111-116.

Humphreys, W. F. 1993b. The significance of the subterranean fauna in biogeographical reconstruction: example from Cape Range peninsula, Western Australia. Records of the Western Australian Museum, Supplement (45): 165-192.

Humphreys, W. F. 1993c. Cave fauna in semi-arid tropical Western Australia: a diverse relict wet-forest fauna. Mémoires de Biospéologie 20: 105-110.

Humphreys, W. F. 2001. Groundwater calcrete aquifers in the Australian arid zone: the context to an unfolding plethora of stygal biodiversity. Records of the Western Australian Museum, Supplement (64): $63-83$.

Jaume, D. and Humphreys, W. F. 2001. A new genus of epacteriscid calanoid copepod from an anchialine sinkhole of northwestern Australia. Journal of Crustacean Biology 21: 157-169.

Jaume, D., Boxshall, G. A. and Humphreys, W. F. 2001. New stygobiont copepods (Calanoida; Misophrioida) from Bundera Sinkhole, an anchialine cenote in north-western Australia. Biological Journal of the Linnean Society 133: 1-24.

Karanovic, I. 1999a. On Pseudocypridopsis n. gen., with a redescription of Pseudocypridopsis clathrata (Klie, 1936) and a first description of the male (Ostracoda, Cypridopsinae). Bulletin Zoologisch Museum Universiteit van Amsterdam 17: 1-6.

Karanovic, I. 1999b. A new genus and two new species of Candoninae (Crustacea, Ostracoda) from Montenegro (SE Europe). Mémoires de Biospéologie 26: 47-57.

Karanovic, I. 1999c. Two interesting species of Candoninae (Crustacea, Ostracoda) from Montenegro (SE Europe). Bulletin de l'Institut Royal des Sciences Naturelles de Belgique, Biologie 69: 47-56.

Karanovic, I. 2000. Pseudocypridopsis petkovskii sp. nov., a stygobiont freshwater ostracod (Crustacea, Ostracoda, Cypridopsinae) from Montenegro (SE Europe). Mitteilungen aus dem Hamburgischen Zoologischen Museum und Institut 97: 59-66.

Karanovic, I. 2001. Meischcandona gen. nov. from Africa, with a key to the genera of the subfamily Candoninae (Crustacea, Ostracoda). Bulletin de l'Institut Royal des Sciences Naturelles de Belgique, Biologie 71: 93-99.

Karanovic, I. 2003. A new Candoninae genus (Crustacea, Ostracoda) from the subterranean waters of Western Australia. Records of the Western Australian Museum 21: 315-332. 
Karanovic, I. and Marmonier, P. 2002. On the genus Candonopsis (Crustacea, Ostracoda, Candoninae) in Australia, with a key to the world recent species. Annales de Limnologie 38: $199-240$.

Karanovic, I. and Marmonier, P. 2003. Three new genera and nine new species of the subfamily Candoninae (Crustacea, Ostracoda, Podocopida) from the Pilbara Region (Western Australia). Beaufortia 53: 1-51.

Karanovic, I. and Petkovski, T. K. 1999a. Two new species of the subfamily Candoninae (Ostracoda) from Montenegro (SE Europe). Crustaceana 72: 603-616.

Karanovic, I. and Petkovski, T. K. 1999b. Two interesting ostracod species from Montenegro (SE Europe). Annales de Limnologie 35: 123-132.

Karanovic, T. and Pesce, G. L. 2002. Copepods from ground waters of Western Australia, VII. Nitokra humphreysi sp. nov. (Crustacea: Copepoda: Harpacticoida). Hydrobiologia 470: 5-12.

Karanovic, T., Pesce, G. L. and Humphreys, W. F. 2001. Copepods from ground waters of Western Australia, V. Phyllopodopsyllus wellsi sp. nov. (Crustacea: Copepoda: Harpacticoida) with a key to world species. Records of the Western Australian Museum 20: 333-344.

Kaufmann, A. 1900. Cypriden und Parwinuliden der Schweiz. Revue Suisse de Zoologie 8: $209-423$.

Kempf, E. K. 1980. Index and bibliography of nonmarine ostracods. Part 1: Index A. Sonderveroeffentlichungen des Geologisches Institut der Universitaet zu Koeln 35: 1-188.

Kempf, E. K. 1997. Index and bibliography of nonmarine ostracods. Part 6: Index A, Supplement 1. Sonderveroeffentlichungen des Geologisches Institut der Universitaet zu Koeln 109: 1-142.

Klie, W. 1938. Ostracoda, Muschelkrebse. Die Tierwelt Deutschlands und der angrenzenden Meeresteile nach ihren Merkmalen und nach ihrer Lebensweise 34: 1-230.

King, R. L. 1855. On Australian Entomostracans. Papers and Proceedings of the Royal Society of Tasmania 3: 56-75.

Krstic, N. 1972. Rod Candona (Ostracoda) iz kongerijskih slojeva juznog dela Panonskog Basena. [Genus Candona (Ostracoda) from Congerian Beds of Southern Pannonian Basin]. Srpska Akademija Nauka i Umetnosti, Posebna Izdanja, Beograd, 145 pp. [In Serbian]

Krstic, N. and Guan S.-Z. 2000. A proposal for the systematics of the subfamily Candoninae (Ostracoda) with the description of the Macedocandona, new genus. Geologica Macedonica 14: $25-48$.

Lee, W. and Huys, R. 2002. A new genus of groundwater Ameiridae (Copepoda, Harpacticoida) from boreholes in Western Australia and the artificial status of Stygonitocrella Petkovski, 1976. Bulletin of the Natural History Museum, Zoology Series 68: 39-50.

Marmonier, P. and Danielopol, D. L. 1988. Decouverte de Nannocandona faba Ekman (Ostracoda, Candoninae) en basse Autriche. Son origine et son adaptation au milieu interstitiel. Vie et Milieu 38: 35-48.

Martens, K. 1987. Homology and functional morphology of the sexual dimorphism in the antenna of Sclerocypris Sars, 1924 (Crustacea, Ostracoda, Megalocypridinae). Bijdragen tot de Dierkunde 57: 183-190.

Martens, K. 1992. On Namibcypris costata n. gen, n. sp. (Crustacea, Ostracoda, Candoninae) from a spring in northern Namibia, with the description of a new tribe and a discussion on the classification of the Podocopina. Stygologia 7: 27-42.

Martens, K. 1998. General morphology of non-marine ostracods. Pp. 57-75. In: Martens, K. (Ed.) Sex and Parthenogenesis: Evolutionary Ecology of Reproductive Modes in Non-ma- 
rine Ostracods. Backhuys Publishers, Leiden, $321 \mathrm{pp}$.

Mazepova, D. F. 1990. Rakushkovye Rachki (Ostracoda) Baykala. [Ostracoda of Lake Baikal]. Nauka Sibirskoe Otdelenis, Novosibirsk, 471 pp. [In Russian]

Meisch, C. 1996. Contribution to the taxonomy of Pseudocandona and for related genera, with the description of Schellencandona nov. gen., a list of the Candoninae genera, and a key to the European genera of the subfamily (Crustacea, Ostracoda). Bulletin de la Société des Naturalistes Luxembourgeois 97: 211-237.

Meisch, C. 2000. Freshwater Ostracoda of Western and Central Europe. In: Schwoerbel, J. and Zwick, P. (Eds) Süsswasserfauna von Mitteleuropa 8/3. Spektrum Akademischer Verlag, Heidelberg, Berlin, 522 pp.

Müller, G. W. 1900. Deutschlands Süsswasser-Ostracoden. Zoologica, Original-Abhandlungen aus dem Gesamgebiete der Zoologie 12 (30): 1-112.

Pesce, G. L. and De Laurentis, P. 1996. Copepods from ground waters of Western Australia, III. Diacyclops humphreysi n. sp. and comments on the Diacyclops crassicaudis-complex (Copepoda, Cyclopidae). Crustaceana 69: 524-531.

Pesce, G. L., De Laurentis, P. and Humphreys, W. F. 1996a. Copepods from ground waters of Western Australia. I. The genera Metacyclops, Microcyclops and Apocyclops (Crustacea: Copeoda: Cyclopidae). Records of the Western Australian Museum 18: 67-76.

Pesce, G. L., De Laurentis, P. and Humphreys, W. F. 1996b. Copepods from ground waters of Western Australia, II. The genus Halicyclops (Crustacea: Copepoda: Cyclopidae). Records of the Western Australian Museum 18: 77-85.

Petkovski, T. and Karanovic, I. 2000. On Eucandona balatonica (Daday, 1894) and Eucandona levanderi (Hirschman, 1912), two rare and little known ostracod species (Crustacea, Ostracoda). Mésogée 58: 77-84.

Poore, G. C. B. and Humphreys, W. F. 1992. First record of Thermosbaenacea (Crustacea) from the Southern Hemisphere: a new species from a cave in tropical Western Australia. Invertebrate Taxonomy 6: 719-725.

Poore, G. C. B. and Humpreys, W. F. 1998. First record of Spelaeogriphacea (Crustacea) from Australia: a new genus and species from an aquifer in the arid Pilbara of Western Australia. Crustaceana 71: 721-742.

Sywula, T. 1974. Malzoraczki (Ostracoda). Fauna Slodkowodna Polski 24, Polska Akademis Nauk, Warszawa, 315 pp. [In Polish]

Vávra, W. 1891. Monographie der Ostracoden Böhmens. Archiv der Naturwissenschaftlichen Landesdurchforschung von Böhmen 8 (3): 1-116.

Watts, C. H. S. and Humphreys, W. F. 1999. Three new genera and five new species of Dytiscidae (Coleoptera) from underground waters in Australia. Records of the South Australian Museum 32: 121-142.

Wilson, G. D. F. and Ponder, W. F. 1992. Extraordinary new subterranean isopods (Peracarida: Crustacea) from Kimberley region, Western Australia. Records of the Australian Museum 44: 279-298.

Yager, J. and Humphreys, W. F. 1996. Lasionectes exleyi sp. nov., the first remipede crustacean record from Australia and Indian Ocean, with a key to the world species. Invertebrate Taxonomy 10: 171-187. 